Word count: $\sim 7300$

\title{
Recovering the primary geochemistry of Jack Hills zircons through quantitative estimates
} of chemical alteration

\author{
Elizabeth A. Bell ${ }^{*}, 1$, Patrick Boehnke ${ }^{1}$, T. Mark Harrison ${ }^{1}$
}

${ }^{1}$ Dept. of Earth, Planetary, and Space Sciences, University of California, Los Angeles

Los Angeles, CA 90095

*Corresponding author: ebell21@ucla.edu; 310-206-2940

\section{Abstract}

Despite the robust nature of zircon in most crustal and surface environments, chemical alteration, especially associated with radiation damaged regions, can affect its geochemistry. This consideration is especially important when drawing inferences from the detrital record where the original rock context is missing. Typically, alteration is qualitatively diagnosed through inspection of zircon REE patterns and the style of zoning shown by cathodoluminescence imaging, since fluid-mediated alteration often causes a flat, high LREE pattern. Due to the much lower abundance of LREE in zircon relative both to other crustal materials and to the other REE, disturbance to the LREE pattern is the most likely first sign of disruption to zircon trace element contents. Using a database of 378 (148 new) trace element and 801 (201 new) oxygen isotope measurements on zircons from Jack Hills, Western Australia, we propose a quantitative framework for assessing chemical contamination and exchange with fluids in this population. The Light Rare Earth Element Index is scaled on the relative abundance of light to middle REE, or $\mathrm{LREE}-\mathrm{I}=(\mathrm{Dy} / \mathrm{Nd})+(\mathrm{Dy} / \mathrm{Sm})$. LREE-I values vary systematically with other known 
22 contaminants (e.g., Fe, P) more faithfully than other suggested proxies for zircon alteration

$23(\mathrm{Sm} / \mathrm{La}$, various absolute concentrations of LREEs) and can be used to distinguish primary

24 compositions when textural evidence for alteration is ambiguous. We find that zircon oxygen

25 isotopes do not vary systematically with placement on or off cracks or with degree of LREE-

26 related chemical alteration, suggesting an essentially primary signature. By omitting zircons

27 affected by LREE-related alteration or contamination by mineral inclusions, we present the best

28 estimate for the primary igneous geochemistry of the Jack Hills zircons. This approach increases

29 the available dataset by allowing for discrimination of on-crack analyses (and analyses with

30 ambiguous or no information on spot placement or zircon internal structures) that do not show

31 evidence for chemical alteration. It distinguishes between altered and unaltered samples in

32 ambiguous cases (e.g., relatively high Ti), identifying small groups with potentially differing

33 provenance from the main Jack Hills population. Finally, filtering of the population using the

34 LREE-I helps to more certainly define primary correlations among trace element variables, 35 potentially relatable to magmatic compositional evolution.

36 Keywords: zircon, Hadean, early Earth, rare earth element, trace element

\section{1. Introduction}

Detrital zircons from Jack Hills, Western Australia range up to nearly $4.4 \mathrm{Ga}$ in age and

39 record an abundance of geochemical information about the crust during Earth's first few hundred

40 million years (Holden et al., 2009; Harrison, 2009). High $\delta^{18} \mathrm{O}$ among some zircons has been

41 interpreted as evidence for low-temperature rock-water interactions during this time (e.g.,

42 Mojzsis et al., 2001; Peck et al., 2001; Harrison et al., 2008), and low average Ti-in-zircon

43 crystallization temperatures $\left(\mathrm{T}^{\mathrm{x} l \mathrm{ln}}\right)$ suggest near granitic minimum melting conditions for the

44 source magmas of the zircons (Watson and Harrison, 2005). The granitic primary mineral 
45 inclusion suite, dominated by quartz and muscovite (Hopkins et al., 2008, 2010; Bell et al., 46 2015b; cf. Rasmussen et al., 2011), further supports granitic source rocks for the zircons. Their 47 relatively unradiogenic Lu-Hf systematics have been interpreted as indicating continental-like 48 material in the source throughout the Hadean (>4 Ga) eon (e.g., Harrison et al., 2005, 2008; Bell et al., 2014; cf. Kemp et al., 2010) and among the more numerous younger zircons (e.g., Amelin 50 et al., 1999; Bell et al., 2011).

Zircon incorporates many petrologically useful minor and trace elements, such that they

52 are a potentially rich yet currently underexploited source of petrologic information on Earth's

53 first few hundred million years. However, the extent to which chemical alteration may have

54 obscured the primary chemistry of the Jack Hills population, and thus its implications for the

55 Hadean, has been a source of controversy. Although many studies have used the trace element 56 contents of the zircons to argue for various igneous or metamorphic origins (e.g., Peck et al., 57 2001; Crowley et al., 2005; Watson and Harrison, 2005; Cavosie et al., 2006; Coogan and and Schaltegger, 2003 for zircon in general). For instance, hydrothermally altered zircon often

62 shows a high, flat light rare earth element (LREE) pattern relative to the normal, high ratios of 63 the heavy rare earth elements (HREE) to the LREE in magmatic zircons (e.g., Hoskin and 64 Schaltegger, 2003). Such apparently altered LREE patterns are seen among a minority of Jack 65 Hills zircons (Maas et al., 1992; Peck et al., 2001; Hoskin, 2005; Cavosie et al., 2006), 66 prompting Hoskin (2005) to ascribe them to hydrothermal alteration rather than to high LREE 67 contents among Hadean magmas. Cavosie et al. (2006) attributed similar high-LREE patterns 
among a minority of zircons to alteration processes other than hydrothermal, given their lack of correlation with anomalous $\delta^{18} \mathrm{O}$. They instead attributed such patterns to contamination by phosphate inclusions or local LREE enrichment at very low water/rock ratios in radiationdamaged regions.

It is known that a variety of metamorphic events affected the ca. $3 \mathrm{Ga}$ host conglomerate of the Jack Hills zircons and its surrounding environs during the Archean and Proterozoic (e.g., Myers et al., 1988), with several recognized chemical effects on the zircons themselves and their host rocks (e.g., Rasmussen et al., 2011; Pidgeon, 2014). Metasediments at the Jack Hills discovery site fail the paleomagnetic conglomerate test, indicating that they were remagnetized after deposition (Weiss et al., 2015; cf. Tarduno et al., 2015). In addition to Archean and Proterozoic metamorphic events (Myers et al., 1988; Fletcher et al., 1988), granitoids intruded the region at ca. 3.0 and 2.6 Ga (Myers et al., 1988; Spaggiari et al., 2007) along with a phase of volcanism at $1.8 \mathrm{Ga}$ (Wilde, 2010), and mafic dikes associated with the Marnda Moorn and Warrakurna Large Igneous Provinces intruded the region at ca. 1.2 Ga (Spaggiari et al., 2007). Any of these tectonothermal events could potentially create conditions conducive to zircon alteration.

Many Jack Hills zircons contain cracks which are associated with higher $\mathrm{Ti}$ and $\mathrm{Fe}$ contents relative to the magmatic zircon lattice (Harrison and Schmitt, 2007) and appear to contain slightly lower $\delta^{18} \mathrm{O}$ values (Trail et al., 2007). Cracks in the zircons are often mineralized (Rasmussen et al., 2011; Bell et al., 2015b; Caro et al., 2008), with the dominant phases being quartz, xenotime, Fe oxides, muscovite, and minor monazite (Bell et al., 2015b). These phases are common in the host metaconglomerate (Rasmussen et al., 2010, 2011). Some but not all inclusions in contact with cracks in the zircons have been altered by fluid ingress over 
91 geologic time (Bell et al., 2015b). It has so far been unclear, however, to what extent these

92 crack-related zones of alteration may affect the Jack Hills zircon geochemical record as a whole

93 and to what extent the zircons may indeed retain their primary igneous chemistry.

94 To address these issues, we present a database of published and new trace element and oxygen isotope compositions on a variety of Jack Hills zircon samples with U-Pb dates from 4.2

96 to $2.2 \mathrm{Ga}$ which range from uncracked and magmatically zoned to highly cracked and/or

97 metamict grains. We investigate the relationship of various trace element concentrations and $98 \delta^{18} \mathrm{O}$ values to likely alteration features such as cracks, metamict regions, or disrupted zoning as 99 shown by cathodoluminescence (CL) in order to define quantitative estimates for the degree and mechanisms of chemical alteration of Jack Hills zircons, and potential structural markers for 101 such alteration.

\section{Trace elements in zircon}

Considerable effort has been expended in developing various aspects of zircon trace 104 element chemistry as proxies for the conditions of zircon formation or for discriminating the 105 provenance of detrital zircons. Several trace element contents and ratios in zircon are 106 quantitative proxies for useful properties of magmas, including the Ti content as a proxy for 107 crystallization temperature (Watson and Harrison, 2005; Ferry and Watson, 2007) and Ce/Ce* as 108 a proxy for $f_{\mathrm{O}_{2}}$ (Trail et al., 2011). Other trace element concentrations and ratios, especially of 109 the rare earth elements (REE), provide less certain and less quantitative information about 110 igneous zircon origins. They may record useful information about magmatic compositional 111 evolution or source region (e.g., Claiborne et al., 2010; Barth et al., 2013; cf. Hoskin et al., 112 2000). Their usefulness as provenance indicators is a subject of debate (e.g., Hoskin and Ireland, 113 2000; Belousova et al., 2002). However, in order to properly assess the potential of trace 
114 element chemistry as a discriminant of zircon provenance, it must first be established that the 115 effects of later alteration can be distinguished from the original chemistry of the zircon as 116 inherited from the magma (hereafter, 'primary chemistry').

117 Although normally robust, under certain circumstances zircons can be chemically altered.

118 Damage to or amorphization of the zircon crystal structure is a common factor, as radiation119 damaged zircon will often swell progressively with accumulating damage. This may allow 120 permeation by fluids, with consequent chemical alteration (e.g., Geisler et al., 2003a) and 121 disturbance to the U-Pb system (Mezger and Krogstad, 1997). Swollen metamict regions may 122 also cause the formation of cracks in surrounding, less U-rich zircon, allowing fluid ingress, as 123 demonstrated at Jack Hills by the evidence for crack mineralization (Rasmussen et al., 2011; Bell 124 et al., 2015b; Harrison and Schmitt, 2007; Caro et al., 2008). This process can lead to chemical 125 alteration of metamict regions in the zircon or, in the case of mineralized cracks, contaminate in 126 situ analyses which sample both pristine zircon and material residing in cracks due to accidental 127 overlap. Recrystallization in the solid state may also occur under high-temperature 128 metamorphism and result in some redistribution of trace elements within the zircon (e.g., Hoskin 129 and Black, 2000), although not necessarily effecting exchange between zircon and the 130 surrounding geologic environment. In this paper we will focus on the effects of contamination 131 by and exchange with external fluids, as these processes likely affect zircon across a larger range 132 of geologic settings than solid-state recrystallization.

Exposure to hydrothermal fluid may result in chemically altered zircon (Geisler et al., $1342003 a, b)$ or in replacement of the zircon by other phases such as zirconolite, various REE135 phosphates, carbonates, oxides, and hydroxides (Giere, 1996). Hydrothermal alteration of zircon 136 commonly results in enrichments in LREE and various other incompatible elements, along with 
137 light elements such as Ca, Al, and Fe (Hoskin, 2005; Hoskin and Schaltegger, 2003; Yang et al.,

138 2014; Geisler et al., 2003b), and a loss of REE, U, Th, and other heavy trace elements (Geisler et 139 al., 2003a; Hoskin and Schaltegger, 2003). In addition, some studies of metamorphic zircon 140 have also proposed effects of aqueous chemical alteration. Vavra et al. (1999) document CL141 bright secondary features cross-cutting primary igneous zoning within altered zircons, and 142 interpret them as resulting from fluid-related alteration and exchange of various trace elements. 143 As an additional consideration, the diffusivity of oxygen in zircon is orders of magnitude higher 144 in the presence of water, potentially leading to oxygen isotope exchange during fluid-related 145 alteration (Watson and Cherniak, 1997).

146 3. Materials and Methods

147 We combined new SIMS data for U-Th-Pb systematics, trace elements, and oxygen 148 isotopes with literature data for Jack Hills zircons to assess relationships with microstructures 149 ranging from likely pristine to clearly altered. Ion microprobe measurement craters were imaged 150 via SEM and classified into those falling on cracks or obvious inclusions and those falling on 151 uncracked and apparently inclusion-free regions of the host zircon. We chose this textural 152 approach due to previous evidence for alteration of the zircons along cracks (e.g., Trail et al., 153 2007; Harrison and Schmitt, 2007). Cathodoluminescence (CL) imaging using a Tescan Vega 3 154 with a 3-channel color CL detector was used to determine the type of zoning in regions sampled 155 by SIMS measurements. We categorize the degree of CL alteration into the categories 156 Magmatic, Altered (any potential former magmatic zoning obliterated), Altered Magmatic 157 (magmatic zoning still recognizable but clearly altered in certain regions, e.g. blurring of 158 originally fine oscillatory zoning or patches of faded zoning), and Ambiguous (showing no clear 159 zoning; often homogeneous and CL-inactive) after the classification scheme of Bell et al. (2014). 
160 Samples are further grouped largely by the apparent style of altered zoning observed. This

161 includes "patchy" structures (e.g., Corfu et al., 2003; irregular zoning subdividing the grain into

162 smaller regions), faded/blurred/darkened magmatic zoning (e.g., broadening or fading of

163 oscillatory zoning), and cloudy or hazy zoning (zoning indistinct in a bright and somewhat

164 diffuse luminescence). We also include in the Altered category bright, sometimes cross-cutting

165 features similar to those which have been interpreted as fluid-related alteration in other settings

166 (e.g., Vavra et al., 1999). We use "patchy" as the default category for alteration as it is the most

167 common type among our sample set as well as in the literature data we draw from. Grains with

168 various types of alteration are put into the "patchy" category. Ambiguous grains are mostly

169 homogeneous, and homogeneous grains are usually CL inactive. Magmatic zoning includes

170 unaltered oscillatory zoning (e.g., Corfu et al., 2003). Sector zoning is also characteristic in

171 many magmatic settings, but we use oscillatory zoning as the benchmark due to the lesser chance

172 of mistaking it for another zoning style, particularly in broken zircons. Examples of the

173 alteration microstructures used for our classifications are shown in Figure 1. Literature data,

174 including $\mathrm{U}-\mathrm{Pb}$ age, multicollector oxygen isotope, and trace element results, were combined

175 from a variety of sources which report the relationship of analysis spots to zoning style and/or

176 cracks (Cavosie et al., 2004, 2005, 2006; Trail et al., 2007; Bell and Harrison, 2013; Bell et al.,

177 2014; Bell et al., 2015a) and those which did not report these relationships (Crowley et al., 2005;

178 Bell et al., 2011; Harrison et al., 2008; Peck et al., 2001). We use those analyses from regions

179 containing various potential alteration features (cracks, zoning) to assess chemical markers for

180 alteration. Since omitting analyses with uncertain placement may in many cases involve

181 ignoring a large amount of data, we later evaluate these data by the same chemical markers to 
182 assess whether they can also be used for reconstructions of the primary zircon chemistry. All

183 data may be viewed in the supplementary materials Tables EA-1 through EA-3.

$184 \quad 3.1$ Samples and CL zoning styles

185 The majority of data come from zircons taken from a ca. 3 Ga conglomeratic quartzite at 186 the discovery site (Compston and Pidgeon, 1986). These samples constitute the most studied 187 population at Jack Hills and are hereafter referred to as "discovery site zircons". In the 188 supplementary data tables EA-1 through EA-3, all samples except those beginning with the 189 designation "JHC2" are from this population. This population consists of typically rounded, 190 translucent, colorless to deep red grains up to several hundred microns in their longest 191 dimension. They range in age ca. 4.4-3.0 Ga, with a major age peak at ca. $3.4 \mathrm{Ga}$ and a minor 192 age peak at ca. 4.1 Ga (e.g., Holden et al., 2009). In addition to zircons from the discovery 193 outcrop, we include zircons from a nearby metasediment (JHC2; supplementary tables EA-2 and 194 EA-3) which are similar in size and rounding to the discovery site zircons but largely opaque and 195 yellow-brown. Like the discovery site zircon, these yellow zircons were separated using 196 standard heavy liquid separation, with the exception that they were not subject to magnetic 197 separation. Cathodoluminescence imaging reveals remnant magmatic zoning in several of these 198 grains, although it has been obliterated in many (see Fig. 1). Mineral inclusions are far more 199 numerous among this population and commonly consist of quartz and xenotime. Because of 200 their dominant coloring, this sample set is hereafter referred to as "yellow series" zircons. Age 201 (EA-3) and trace element contents (EA-2) are reported for both discovery site and yellow series 202 zircons. Oxygen isotope measurements are reported only for discovery site zircons (EA-1).

203 3.2Ion microprobe analyses 
All ion microprobe analyses were undertaken on the CAMECA ims 1270 ion microprobe

205

206

207

208

209

210

211

212

213

214

215

216

217

218

219

220

221

222

223

224

225

226

at UCLA. U-Th- $\mathrm{Pb}$ dating was accomplished using a ca. $15 \mathrm{nA} \mathrm{O}$-primary beam focused to a ca. $30 \mu \mathrm{m}$ spot (e.g., Mojzsis et al., 2003). We used zircon age standard AS3 (1099 \pm 1 Ma, Paces and Miller, 1993). We measured trace elements including Ti, Fe, Y, REE, Hf, Th, and U using a ca. $15 \mathrm{nA} \mathrm{O}^{-}$primary beam focused to a ca. $30 \mu \mathrm{m}$ spot. A $-100 \mathrm{~V}$ offset in the sample high voltage was used to suppress molecular interferences. Instrumental mass fractionation and relative sensitivity factors for various elements were determined using standard glass NIST 610 with additional comparison to the 91500 standard zircon (e.g., Wiedenbeck et al., 2004) for accuracy. The use of NIST 610 glass allows for the standardization of all studied trace elements except for $\mathrm{Fe}$, since there is a potentially unresolved interference of ${ }^{40} \mathrm{CaOH}^{+}$at mass ${ }^{57} \mathrm{Fe}$. We therefore present estimated Fe concentrations for zircons as Fe*. Oxygen isotopes were measured in multicollection mode with a $\sim 2 \mathrm{nA} \mathrm{Cs}{ }^{+}$primary beam focused into a $\sim 20 \mu \mathrm{m}$ spot. For more details on the analytical method see Trail et al. (2007). The AS3 zircon standard (5.34\%; Trail et al., 2007) was used for sample-standard comparison.

\section{Results}

We present 201 new oxygen isotope analyses on Jack Hills discovery site zircons, along with 600 published analyses (see Table EA1). In addition, we present 148 new trace element analyses on Jack Hills zircons, along with 230 published analyses (see Table EA2). U-Pb isotopic data for newly dated grains are shown in Table EA3. Yellow-series and discovery site zircons are distinguished in tables EA-2 and EA-3 and in Figures 2-6. Results for crack-free and crack-intersecting analyses among the discovery site zircons, as well as yellow series samples, are shown separately in Figures 2-4. We do not at this time include those analyses on discovery site zircons with uncertain spot placement with respect to cracks or other features (either from 
227 this study or previous studies) in Figures 4-6 so as not to obscure potential microstructural 228 origins of variations in trace chemistry. Yellow series zircons are similar enough in chemistry 229 and SEM imaging reveals nearly universally disrupted, highly cracked surfaces (see e.g. Fig. 1e, 230 f) such that we consider them as one group regardless of microstructural features. For most trace 231 element variables there is considerable overlap among the analyses on crack-free surfaces, those 232 falling on cracks, and those on the yellow series grains (see Figs. 2-4). However, despite the 233 many similarities, the on-crack versus crack-free discovery site zircon analyses differ 234 significantly (using the Mann-Whitney U test, a nonparametric statistical test for whether two 235 samples come from the same population) in several trace element variables: P, LREE/HREE (as 236 shown by Nd/Yb), $\mathrm{T}^{\mathrm{xlln}}$, Fe, HREE/MREE (shown by $\mathrm{Yb} / \mathrm{Gd}$ ), and U. Certain signals are seen 237 mainly or exclusively among the crack-intersecting measurements: high $\mathrm{P}$ (>1000 ppm), high 238 LREE/HREE $(\mathrm{Nd} / \mathrm{Yb}>0.01)$, high $\mathrm{Ti}\left(>900^{\circ} \mathrm{C}\right.$ apparent $\left.\mathrm{T}^{\mathrm{xlln}}\right)$, high $\mathrm{Fe}(>1000 \mathrm{ppm})$, and low 239 HREE/MREE $(\mathrm{Yb} / \mathrm{Gd}<10)$. Analysis spots on cracks and uncracked but $\mathrm{CL}-$ altered regions in 240 the discovery site zircons are slightly more likely to show high $\mathrm{Th} / \mathrm{U}$, low $\mathrm{Ce} / \mathrm{Ce}$, and low $\delta^{18} \mathrm{O}$, 241 but these differences are not statistically significant. Each of the aforementioned trace chemistry 242 differences is also seen between the crack-free and yellow-series analyses, with the exception 243 that the Mann-Whitney U test shows the differences to be significant even for Th/U and Ce/Ce*. $244 \mathrm{Y}$ and HREE contents are similar between on-crack and crack-free analysis spots. Comparison 245 of yellow-series and discovery site zircons on Figures 3-6 reveals that many of the differences 246 between the cracked and uncracked discovery site analyses also hold for yellow-series versus 247 uncracked discovery site zircons: yellow-series grains are more likely to show higher P, 248 LREE/HREE, Ti, Fe, and low HREE/MREE. They also tend to be higher in Y and HREE 249 contents than discovery site zircons regardless of spot placement. Yellow series zircons are on 
250 average higher in $\mathrm{U}$, and range up to $20,000 \mathrm{ppm} \mathrm{U}$. Based both on their $\mathrm{U}$ contents and their

251 highly disrupted microstructures they are most likely metamict. U above 1000 ppm is only seen

252 among crack-intersecting analyses in discovery site zircons. Among most analyses, $\mathrm{Nd} / \mathrm{Yb}$

253 correlates directly with $\mathrm{P}$ and inversely with $\mathrm{Ce} / \mathrm{Ce}$, while $\mathrm{T}^{\mathrm{xlln}}$ correlates with $\mathrm{Fe}$ (and also Mn,

254 although this is not shown on Figure 4). Sm/La varies between $\sim 1$ and 1000 (Figure 4e, f).

255 Among cracked and metamict analyses Sm/La varies inversely with the other likely alteration

256 signals of $\mathrm{P}$ and $\mathrm{Fe}$, but there is little evidence of a relationship between these variables among

257 crack-free analysis spots at similar Sm/La values. Zircons vary between 2 and $11 \%$ in

$258 \delta^{18} \mathrm{O}_{\text {SMOW. }}$

Crack-free analyses falling in regions of different CL zoning (see Figure S3 of Electronic

260 Annex EA4) show few chemical distinctions by group, with the exception that regions

261 characterized by bright features are typically low in $U$ and that dark, homogeneous regions are

262 typically low in $\mathrm{T}^{\mathrm{xlln}}$ and high in $\mathrm{U}$ and $\mathrm{Hf}$ (similar to the observations of Bell and Harrison, 2632013 for their study specifically of ca. 3.9 Ga zircons).

\section{5. Discussion}

Jack Hills zircons display a variety of geochemical signatures potentially related to

266 alteration, magmatic compositional evolution, or distinct provenances. Although $\delta^{18} \mathrm{O}$ does not

267 differ significantly between cracks and uncracked surfaces, several trace element concentrations

268 and ratios show distinct trends among the cracked, uncracked, and yellow-series populations.

269 However, the significant overlap in the ranges of many elemental concentrations and ratios

270 between cracked and non-cracked regions suggests that discarding analyses for which the

271 analysis spot overlaps cracks (e.g., Bell and Harrison, 2013) removes a significant amount of 272 unaltered chemical data. 
Deconvolving the primary trace element chemistry of zircons from alteration overprints

274

275

276

277

278

279

280

281

282

283

284

285

286

287

288

289

290

291

292

293 294 hydrothermal signatures.

and interpreting that data in terms of Hadean magma chemistry would be strengthened by knowing alteration signatures. Steep, primary REE patterns similar to the Type I patterns of Hoskin (2005) and Cavosie et al. (2006) are the most common and make up the vast majority of analyses not falling on cracked regions (see Figure 3). High, flat-LREE patterns (Type II, Hoskin, 2005; Cavosie et al., 2006) are displayed by a small minority of analyses not falling on cracks but are more common among analyses on cracks and nearly universal for the yellow series zircons (see Figure 3). We therefore focus on the LREE as an alteration indicator.

\subsection{An LREE-based alteration index}

High, flat LREE patterns are commonly associated with zircon alteration (e.g., Hoskin, 2005; Hoskin and Schaltegger, 2003; Cavosie et al., 2006). This observation is consistent with the lower abundance (and opposite slope) of LREE in zircon compared to many other materials for example, the average continental crust has a negative REE slope and varies between $85 \mathrm{x}$ chondritic for La and 27 x chondritic for Sm(crust: Rudnick and Gao, 2003; chondrites: Anders and Grevesse, 1989), an order of magnitude or more above La contents often seen in primary zircon. Hoskin (2005) reported $(\mathrm{Sm} / \mathrm{La})_{\mathrm{N}}$ values for hydrothermal zircon from the Boggy Plain Zoned Pluton of 1.5-4.4, contrasted with the values of 22-110 for magmatic zircon, demonstrating the relative LREE-flatness of hydrothermally altered zircon and the covariance of $(\mathrm{Sm} / \mathrm{La})_{\mathrm{N}}$ with quantities such as Ce/Ce*. Similarly, Cavosie et al. (2006) defined their altered

"Type II" samples as those with chondrite-normalized $\mathrm{La}_{\mathrm{N}}>1$ and $\operatorname{Pr}_{\mathrm{N}}>10$, and observed that these were generally intermediate between Hoskin (2005)'s fields for magmatic and 
Analyses on cracks and the yellow series Jack Hills zircons do show generally lower $296(\mathrm{Sm} / \mathrm{La})_{\mathrm{N}}$, but there is considerable overlap with the crack-free analyses such that a substantial 297 number of crack-free analyses with otherwise magmatic trace element signatures (low U, low $298 \mathrm{~T}^{\mathrm{x} l \mathrm{ln}}$ ) also display low $(\mathrm{Sm} / \mathrm{La})_{\mathrm{N}}<10$ (below the magmatic range suggested by Hoskin, 2005) and 299 have variable $\mathrm{La}$ and Pr contents. Along with the similar ranges of Sm/La among on-crack and 300 crack-free analyses, differing trends of on-crack and crack-free analyses at similar low Sm/La 301 (on-crack analyses trending toward higher $\mathrm{P}$ and Ti contents with lower $\mathrm{Sm} / \mathrm{La}$, and no obvious 302 trend among the crack-free analyses; Fig. 4c,d) suggests that $\mathrm{Sm} / \mathrm{La}$ is an ambiguous signal of 303 alteration and thus microstructural context is needed to appropriately interpret it. By contrast, all 304 three categories display similar trends between La and Ti or P (Fig. 4a, b), although the on-crack 305 and yellow-series analyses do trend toward higher overall La contents. Similar behavior is seen 306 in plots of $\mathrm{Nd} / \mathrm{Yb}$ vs. Ti (Fig. 4e), with the on-crack and yellow-series analyses again trending 307 toward higher $\mathrm{Nd} / \mathrm{Yb}$.

Given these results coupled with the potential for a range in overall primary REE contents among zircons of differing provenance, the relative abundance of LREE versus the other REE is the preferred predictor for the other aspects of chemical alteration (high Ti, P)

311 identified among the zircons. Since separate processes may change the HREE/MREE slope in 312 zircon as a primary magmatic effect (e.g., Barth et al., 2013; Claiborne et al., 2010) and Yb/Gd 313 varies among our microstructural categories, comparing the LREE to an element intermediate 314 between $\mathrm{Yb}$ and $\mathrm{Gd}$ in ionic radius may help to avoid the effects of other processes. We propose 315 a simple Light Rare Earth Element Index for hydrothermal alteration and contamination (LREE316 I $)$ defined by LREE-I $=(\mathrm{Dy} / \mathrm{Nd})+(\mathrm{Dy} / \mathrm{Sm})$. 
Of the LREE, only $\mathrm{Sm}$ and $\mathrm{Nd}$ are used in the calculation in order to decrease the uncertainties associated with Ce's $f_{\mathrm{O}_{2}}$ dependency and the typical very low abundances of La and Pr. Dy is chosen as a relatively abundant MREE intermediate between Yb and Gd. Nonetheless, LREE-I variants using Gd or Yb instead of Dy correlate well with the LREE-I over most of its range except at very low (altered) values in the Jack Hills population (see Figure S5 in EA4).

As formulated, the LREE-I should decrease with increasing degree of hydrothermal alteration or contamination. Indeed, it exhibits the appropriate correlations with the other 324 indicators of alteration noted among Jack Hills zircons (P, Ti, Fe, U contents; Fig. 5). However, 325 there is a break in slope at LREE-I $<30$ for most investigated quantities, below which alteration indicators increase precipitously as LREE-I decreases (Fig. 5). We interpret this break in slope as separating distinct sets of processes for producing the LREE-I variation, with LREE-I below 30 indicating alteration. Analyses on cracks or metamict surfaces constitute the vast majority of LREE-I<10. Samples with low LREE-I (mostly cracked and metamict surfaces) generally have lower $(\mathrm{Sm} / \mathrm{La})_{\mathrm{N}}$ below 10 and high contents of LREE, although some grains falling into an uncertain region between 10 and 30 range to low LREE contents (Fig. 7a). At higher LREE-I values, no correlation is apparent (Fig. 7). Other trace element quantities which respond slightly to alteration, or which relate also to magma chemistry and thus may not be clear diagnostic 334 indicators for alteration, also show contrasting relationships with LREE-I above and below 30 335 (Fig. 6). Among samples with LREE-I > 30, Th/U and Ce/Ce* are negatively correlated and $336 \mathrm{Yb} / \mathrm{Gd}$ is slightly positively correlated with LREE-I. However, below LREE-I=30, Th/U shows 337 no covariance with LREE-I while $\mathrm{Ce} / \mathrm{Ce}^{*}$ and $\mathrm{Yb} / \mathrm{Gd}$ become much more strongly correlated 338 with LREE-I, pointing again to alteration processes dominating the trace element signatures at 
$340 f_{\mathrm{O} 2}$, however, owing to the nearly universally high apparent $\mathrm{T}^{\mathrm{xlln}}$ among these same samples (Fig. $3416 \mathrm{~d})$.

For the remainder of this paper we consider analyses with LREE-I $<10$ to be clearly 343 altered and those with LREE-I between 10 and 30 to be uncertain. LREE-I>30 indicates a 344 sample that has not undergone contamination or hydrothermal alteration processes and are 345 referred to as primary. Samples with LREE-I $<30$ are not further considered outside of 346 discussions of alteration. We now also include 125 additional trace element measurements both 347 new and from the literature with no or uncertain microstructural context, 96 of which have 348 LREE-I > 30. All trace element analyses are classified into the categories primary, altered, and uncertain in Table EA-5 of the supplementary materials. Better elimination of altered samples 350 using the LREE-I helps to define the ranges of various trace element contents and ratios among 351 the zircons and can help to identify small groups with chemistry that is otherwise of uncertain 352 origin. For instance, after applying our criteria, apparent $\mathrm{T}^{\mathrm{x} l l n}$ values above $\sim 850^{\circ} \mathrm{C}$ are 353 eliminated from the primary dataset, such that the relatively low-temperature (average $\sim 680^{\circ} \mathrm{C}$; 354 similar to that reported by Watson and Harrison, 2005) population resembles even less the 355 temperature spectra of zircons from mafic or impact-related melts (Wielicki et al., 2012). 356 Although the problem of high Ti due to alteration had been previously identified (Harrison and 357 Schmitt, 2007), better establishing the origins of the high-Ti signature will help to clarify 358 ambiguities in the Jack Hills temperature record. There exists a small number of $>800^{\circ} \mathrm{C}$ zircons 359 that might otherwise be assumed to reflect alteration but which screening with the LREE-I 360 reveals is probably primary (Fig. 8a). Similarly, although most altered samples have low Sm/La, 361 zircons falling into the primary category also range to relatively low Sm/La (Fig. 8b).

\subsection{Distinguishing types of alteration}


Without prior knowledge, a search for regions in which primary zircon chemistry remains undisturbed would likely focus only on those regions with original magmatic zoning, concordant $\mathrm{U}-\mathrm{Pb}$ systems, and no cracks. Indeed the vast majority of such regions show magmatic, high LREE-I. However, later alteration may be ambiguous in cases of ancient Pb loss or, apart from the Jack Hills population, among zircons too young for $\mathrm{Pb}$ loss to be reliably distinguished. The 368 typical methods used for extracting zircon from bulk samples (involving pulverization by 369 crushing or electricity) are also likely to produce some cracks which were not present during 370 residence in the crust and thus do not represent sites of chemical alteration. Many regions of 371 Jack Hills zircons showing potential predictors of later disturbance (mainly cracks, but also 372 altered CL zoning, etc.) display high, primary LREE-I - although many cracked regions do show 373 low LREE-I as expected. As such, the LREE-I can reduce ambiguity surrounding alteration of 374 zircon. In addition to more readily identifying altered samples, when applied to populations of 375 zircon it can help to distinguish mechanisms of alteration relevant for understanding the 376 population's post-crystallization geologic history. Known mechanisms of alteration and contamination in the Jack Hills zircons include 378 mineralization of some cracks by foreign phases, consisting mainly of quartz, xenotime, $\mathrm{Fe}$ 379 oxides, monazite, and muscovite (Rasmussen et al., 2011; Bell et al., 2015b). Although these 380 phases were noted filling wide cracks, chemical alteration is evident even among some cracks 381 where a separate phase cannot be identified. Figure 9 shows correlations of various alteration382 related trace element signatures with the concentration of Fe and P (also see plots S8-S10 in 383 EA4). Fe correlates strongly with Ti content (as does Mn). P correlates well with Ti, HREE 384 slope (as shown by $\mathrm{Yb} / \mathrm{Gd}$ ), and most REE+Y contents. REE+Y and $\mathrm{P}$ covariance during 385 magmatic evolution is expected since $\mathrm{P}^{+5}$ (along with $\mathrm{H}^{+}$; de Hoog et al., 2014) can charge- 
386 balance the substitution of $\mathrm{REE}^{+3}$ into tetravalent lattice sites (Finch and Hanchar, 2003), but the

387 distinct slope and much stronger correlation among the altered signatures points to a separate 388 process. Interestingly, Th/U correlates strongly with $\mathrm{P}$ among the altered samples only at $\mathrm{P}<$ $3891000 \mathrm{ppm}$, with higher $\mathrm{P}$ values having relatively flat Th/U $\sim 2.5(\sim 1.5$ when time-corrected for 390 decay, although this correction may or may not be appropriate for alteration features given that 391 they are probably not the same age as their host zircon, to which the correction is presently 392 pegged). A Ti-bearing Fe phase(s) and a REE- (and Ti-?) bearing phosphate(s) are likely. The 393 phosphate is likely not monazite, since a very high $\mathrm{Th} / \mathrm{U}$ ratio relative to zircon would lead to a 394 much stronger correlation between $\mathrm{P}$ and $\mathrm{Th} / \mathrm{U}$. The moderate- Th/U xenotime seen in cracks in 395 Jack Hills zircons (Bell et al., 2015b; Rasmussen et al., 2011) and the discovery site 396 conglomerate matrix (Rasmussen et al., 2010)is a likely candidate, especially as shown by the 397 high correlation among $\mathrm{Y}$ and $\mathrm{P}$ contents among altered samples in Fig. 9d. Host zircons of 398 different age with LREE-I <30 show some variation in their contents of $\mathrm{P}$, Y, and Fe, with 399 Hadean hosts mostly showing lower P, Y, and Fe. Of those <3.6 Ga zircons with very high Fe, $400 \mathrm{P}$, Ti, and Y, many are from the yellow series, but some 4.0-3.6 Ga zircons fall into the same 401 range. Although tentative at present, this might point toward slightly differing alteration styles 402 for zircons of differing age. While the majority of altered signatures are thus traceable to 403 contamination by known secondary phases in the Jack Hills zircons, there are also several 404 samples that display the low LREE-I of hydrothermal alteration but lack the high Fe, Ti, and P 405 contents of the other altered samples. These may be altered by a process that did not deposit 406 phosphate or Fe oxides despite adding LREE, potentially contamination by phases not rich in Ti, $407 \mathrm{Fe}$, and $\mathrm{P}$ or hydrothermal exchange/precipitation of zircon without elevated Ti, Fe, or P. 
The bright, transgressive CL features (similar to features potentially related to fluid 409 alteration in other systems; in this study see, e.g., Fig. 1a, d) sampled away from cracks do not 410 appear to have elevated levels of $\mathrm{P}, \mathrm{Fe}$, or Ti, although they fall largely to the high side of La 411 content and to the low side of $\mathrm{U}$ and $(\mathrm{Sm} / \mathrm{La})_{\mathrm{N}}$. Whether these samples are related is unclear, as 412 the analyses on bright uncracked regions do not differ significantly in other trace element 413 contents or trends from the other uncracked analyses. The samples with low $(\mathrm{Sm} / \mathrm{La})_{\mathrm{N}}$ yet high 414 LREE-I, many of which do not fall on cracks but often on faded or bright CL features, are 415 another interesting case. Whether this signature reflects potential alteration or if the low $416(\mathrm{Sm} / \mathrm{La})_{\mathrm{N}}$ is a magmatic effect is unclear. Interestingly, there is great chemical and oxygen 417 isotopic similarity of many zircons with "altered" CL features (blurred/faded, cloudy, or patchy 418 zoning)with those having magmatic, oscillatory zoning. This may mean that the alteration 419 shown by most "altered" CL does not relate to chemical exchange with the environment. 420 Blurred, faded, or patchy zoning may instead reflect local diffusion of CL-active trace elements 421 without bulk exchange necessarily having occurred with external fluids, given the retention of 422 similar chemistry in clearly magmatically zoned grains (see Figs. S3 and S6 in EA4). Although 423 several patchy and bright regions display high $\delta^{18} \mathrm{O}$ between 8 and $11 \%$ relative to SMOW 424 (Figures 2, 10d), a few magmatically zoned (two uncracked and U-Pb concordant) samples are 425 also seen at these values. The slight if any differences between $\delta^{18} \mathrm{O}$ on cracked and uncracked 426 surfaces, and the lack of correlation between $\delta^{18} \mathrm{O}$ and LREE-I and other trace element quantities 427 (Figure 10), suggest that post-formation alteration has not significantly affected $\delta^{18} \mathrm{O}$. This is a 428 similar result to that of Cavosie et al. (2006) in finding no correlation between altered trace 429 element signatures and anomalous $\delta^{18} \mathrm{O}$, and our data further suggest that the lower $\delta^{18} \mathrm{O}$ found 430 along cracks (e.g., Trail et al., 2007) is not a significant effect, suggesting essentially primary 
$431 \delta^{18} \mathrm{O}$ regardless of spot placement in the Jack Hills zircons. Cavosie et al. (2006) consider the 432 lack of correlation of $\delta^{18} \mathrm{O}$ with chemical alteration features to be evidence against the

433 production of the high-LREE signatures by hydrothermal alteration, since exchange with a 434 hydrothermal fluid should in most cases lead to altered $\delta^{18} \mathrm{O}$ in the zircon lattice (e.g., Valley, 435 2003). However, given that nearly all low-LREE-I signatures in the discovery site zircons occur 436 in analysis pits overlapping cracks, it is likely that the small volume of material either 437 precipitated in or affected by localized fluid alteration along some cracks could have a large 438 effect on trace elements (especially the very low-abundance LREE) while having little effect on 439 zircon $\delta^{18} \mathrm{O}$. Most of these altered signatures probably result from analytical mixing between 440 altered material along (or contaminants precipitated in) cracks and that in the unaltered 441 surrounding zircon volume, such that alteration signatures in the trace-level LREE, P, Ti, and Fe 442 are much more likely to be expressed than in the structural component oxygen. It is clear that 443 fluid ingress has affected the zircons along cracks at some point in their history, given the 444 widespread mineralization of cracks in discovery site zircons (Bell et al., 2015b; Rasmussen et 445 al., 2011). These data do, however, argue against contamination or fluid-related alteration of 446 significant volumes of zircon away from cracks and metamict regions in discovery site zircons 447 (as previously noted by Cavosie et al., 2006).

$448 \quad 5.3$ Primary trace element signatures

449 The reconstructed primary composition of Jack Hills zircons better defines provenance 450 groups that are distinguished by distinct chemistry and clarifies covariations among trace 451 element concentrations or ratios which may be related to zircon provenance. Zircons of all ages 452 show trends between $\mathrm{Th} / \mathrm{U}, \mathrm{Sm} / \mathrm{La}$, and various other trace element quantities (Fig. 11), notably 453 the absolute concentrations of Y and HREEs (shown by Y, Fig. 11a) and their abundance relative 
454 to minor element $\mathrm{Hf}$ (shown by Yb/Hf, Fig. 11b). Correlations with $\mathrm{Hf}$, often related to 455 magmatic compositional evolution (Claiborne et al., 2010), appear to be limited (see Fig. S11 in 456 EA4). The good correlations among Th/U, $\mathrm{P}$, and most REE+Y (represented here relative to Hf 457 as $\mathrm{Yb} / \mathrm{Hf}$ ) may be related to magmatic evolution or variations in source materials, such as 458 fractionation or melting of monazite, apatite, or other phosphate minerals. Additionally, the 459 fractionation of an MREE-concentrating phase such as amphibole (seen as a minor inclusion 460 phase among Hadean zircons; Hopkins et al., 2008, 2010) or sphene (identified in one Hadean 461 zircon inclusion; Hopkins et al., 2010) can decrease the $\mathrm{Yb} / \mathrm{Gd}$ ratio of a magma and can also 462 potentially lead to variations in zircon $\mathrm{Yb} / \mathrm{Gd}$. There is no clear correlation between $\mathrm{Yb} / \mathrm{Gd}$ and 463 Hf content among Hadean zircons of any age, but $\mathrm{Yb} / \mathrm{Gd}$ and $\mathrm{Th} / \mathrm{U}$ show an inverse relationship 464 in all age ranges, as commonly seen in modern settings due to either magmatic compositional 465 evolution or variations in source materials (e.g., Barth et al., 2013; Claiborne et al., 2010).

Although the causes of all primary trace chemistry variations among Jack Hills zircons 467 are not entirely clear (and in some cases may remain somewhat obscure due to the unknown 468 diversity of source rocks), the LREE-I permits better constraints on the ranges of primary trace 469 element contents and ratios. This is especially useful for identifying minority components of the 470 Jack Hills population which might otherwise be overlooked as contamination. For example, 471 although high apparent $\mathrm{T}^{\mathrm{x} l \mathrm{ln}}$ were previously known to be a contamination effect (Harrison and 472 Schmitt, 2007), the cutoff between primary high-temperature zircons and contamination effects 473 was unclear. Using the LREE-I we have shown that although almost all apparent $\mathrm{T}^{\mathrm{xlln}}$ above $474 \sim 850^{\circ} \mathrm{C}$ appear to be associated with alteration, the minority of zircons with $800-850^{\circ} \mathrm{C} \mathrm{T}^{\mathrm{x} l l n}$ are 475 probably recording primary $\mathrm{Ti}$ contents and may represent a minority high-temperature 476 provenance (Figure 8a). The $f_{\mathrm{O}_{2}}$ calculated for the zircons using the Ce/Ce* method of Trail et 
477 al. (2011) shows a range from several log units above FMQ to several log units below (Fig. 6d),

478 similar to their initial dataset for the Hadean zircons. Among zircons with primary chemistry,

479 LREE flatness varies over several orders of magnitude, and its covariance with several other 480 trace element quantities among otherwise primary-seeming Jack Hills zircons (Figure 11d-f), 481 distinct from its behavior among altered samples, suggests that magmatic zircon exhibits 482 characteristic $\mathrm{Sm} / \mathrm{La}$ variations likely related to fractionation of phases such as amphibole or 483 sphene, as mentioned above) which may be suitable for petrologic or provenance purposes. An 484 additional concern is that $\mathrm{Ce} / \mathrm{Ce}^{*}$ serves as an $f_{\mathrm{O} 2}$ proxy (Trail et al., 2011), such that the 485 correlation of $\mathrm{Sm} / \mathrm{La}$ with $\mathrm{Ce} / \mathrm{Ce} *$ (Fig. 11f) brings up the question of whether Sm/La correlates 486 with actual melt $f_{\mathrm{O} 2}$ or whether the $\mathrm{Ce} / \mathrm{Ce} *$ is potentially affected by $\mathrm{REE}$ fractionation as well as 487 by $f_{\mathrm{O}_{2}}$.

\subsection{Implications for zircon trace element studies}

489 Despite their ancient formation (between 3.0 and nearly $4.4 \mathrm{Ga}$ ) and long history of metamorphism in their host conglomerate, most non-metamict Jack Hills zircons do not show 491 clear signs of chemical alteration and appear to preserve their primary chemistry. The LREE-I is 492 a good indicator for fluid-related alteration, especially along some cracks and in metamict 493 regions, and provides a method to also identify alteration in analyses with poor microstructural 494 documentation. Altered Jack Hills zircons can with a few exceptions be explained by 495 mineralization with known secondary phases, made clearer using the LREE-I classification 496 scheme. Some variations thus revealed in the chemistry of altered samples by host zircon age 497 could suggest changing conditions of alteration with time.

498 It is unclear whether the LREE-I cutoff values we adopt here are universal or specific to 499 the Jack Hills zircons. Application of an LREE-I cutoff of 30 to other zircon populations may 
500 not be justified and identifying covariation of trace chemistry in specific populations should 501 override our recommendation. Zircon populations undergoing hydrothermal alteration in fluids 502 of differing composition, or contaminated by differing secondary mineral assemblages, may 503 show correlations distinct from those at Jack Hills. The LREE-I will also be appropriate in many 504 cases of non-hydrous contamination, given the generally high LREE/HREE slope in most crustal 505 materials which could serve as potential contaminants (e.g., glass inclusions). As extraterrestrial 506 zircons become increasingly important in our study of the solar system (e.g., Hopkins and 507 Mojzsis, 2015), they may also show such anhydrous contamination effects suitable for screening 508 by the LREE-I. The LREE-I is more efficient than Sm/La or LREE contents alone at identifying 509 contamination and hydrothermal alteration, and can form the basis for quality filtering of detrital 510 zircon trace element data for provenance determination and other purposes. This study is based on ion microprobe analyses for which small, shallow analysis pits 512 allow identification of spot placement versus cracks in the vast majority of cases by later electron 513 imaging. Since many crack-overlapping analyses show no evidence for chemical alteration, 514 rejecting analyses on cracks will reject the majority of altered samples but also a substantial 515 amount of primary chemical data. However, for other techniques microstructural information 516 may be less clear or nonexistent. Deep laser ablation pits may destroy visual indicators for 517 alteration under the surface of the analyzed zircon. In this case, application of the LREE-I cycle 518 by cycle may help to identify secondary chemistry from now-obliterated features. Similarly, 519 solution ICP-MS analysis, as in the TIMS-TEA method (Schoene et al., 2010), links trace 520 element contents to TIMS U-Pb ages for dissolved volumes of zircon, destroying contextual 521 information. The LREE-I can assist in identifying alteration in these cases as well. Better filters 522 to eliminate the effects of contamination will lead to better understanding the true range of 
523 variation of REE and other trace elements in zircon. This is a crucial first step for better

524 developing this controversial but potentially rich source of information on zircon formation and

525 the chemistry of host magmas.

\section{6. Conclusions}

527 Jack Hills zircons exhibit varying degrees of chemical alteration and secondary 528 mineralization, although most non-metamict zircons have probably not experienced bulk 529 chemical change except along cracks. We introduce the Light Rare Earth Element Index for 530 recognizing contamination by exchange with external fluids or secondary mineralization, or 531 LREE-I = Dy/Nd + Dy/Sm. Among Jack Hills zircons, low LREE-I $(<30)$ indicates alteration 532 and the quantity shows correlations with several known alteration features (high $\mathrm{P}, \mathrm{Ti}, \mathrm{Fe}$, $533 \mathrm{REE}+\mathrm{Y}$ ), and provides better identification of altered samples than use of $\mathrm{Sm} / \mathrm{La}$ or specific 534 LREE concentrations alone. Better identification of the alteration features helps in identifying 535 causes of alteration and contamination, which in Jack Hills zircons is consistent with the 536 secondary phases known to fill cracks. Analysis spots in regions with altered CL zoning do not 537 show distinct trace element chemistry relative to magmatically zoned regions and display similar 538 correlations among trace element quantities, suggesting that these CL patterns were not imparted 539 by chemical exchange with the environment. Primary trace element contents and ratios among 540 the zircons exhibit potential signatures of variations in source magma chemistry and mineral 541 fractionation. Better identification of primary ranges in chemistry may help identify specific 542 provenances in the future, and better identification of alteration features may help to identify 543 some aspects of the post-crystallization history of out-of-context zircons. 


\section{Acknowledgments}

Most of the new oxygen isotope analyses presented in this study were conducted by Haibo Zou at UCLA. We thank Axel Schmitt and Rita Economos for help with our other ion microprobe analyses. The ion microprobe facility at UCLA is partially supported by a grant from the Instrumentation and Facilities Program, Division of Earth Sciences, NSF (EAR-1339051). This research was supported by a Simons Collaboration on the Origins of Life Postdoctoral Fellowship (293529) to E.A.B. and an NSF grant (EAR-0948724) to T.M.H.

\section{Figure Captions}

Figure 1: Cathodoluminescence (CL) images of zircons showing examples of alteration features and remnant magmatic zoning. A-D: discovery site zircons; E-F: yellow series zircons. Samples shown are A) RSES 82-5.14, B) RSES 80-2.8, C) RSES 82-15.19, D) RSES 82-14.11, E) JHC 2-2.5, and F) JHC 24.5. Note dark CL, overprinted or absent magmatic zoning, and pervasive mineralization of yellow-series metamict zircons. Scale bars in each panel are $50 \mu \mathrm{m}$.

Figure 2: $\delta^{18} \mathrm{O}$ vs. age for Jack Hills zircons. A) By relationship to cracks and U-Pb discordance. "Conc." = $\leq 10 \%$ discordant; "Disc." = $>10 \%$ discordant. B) By relationship to CL zoning, undifferentiated by relationship to cracks. "Mag" = magmatically zoned; "hom" = homogeneous; "b.r." = bright replacement.

Figure 3: REE plot fields for crack-free, on-crack, and metamict SIMS analysis spots on Jack Hills zircons.

Figure 4: Various trace element quantities and their variation among the crack-free, on-crack, and yellow seriesanalysis spots. A) apparent $\mathrm{T}^{\mathrm{xlln}}$ vs. $\left.\mathrm{La}_{\mathrm{N}} ; \mathrm{B}\right) \mathrm{P}$ vs. $\left.\mathrm{La}_{\mathrm{N}} ; \mathrm{C}\right)$ apparent $\mathrm{T}^{\mathrm{xlln}}$ vs. $(\mathrm{Sm} / \mathrm{La})_{\mathrm{N}}$; D) P vs. $\left.(\mathrm{Sm} / \mathrm{La})_{\mathrm{N}} ; \mathrm{E}\right)$ apparent $\mathrm{T}^{\mathrm{xlln}}$ vs. $\left.\mathrm{Nd} / \mathrm{Yb} ; \mathrm{F}\right) \mathrm{P}$ vs. $\mathrm{Nd} / \mathrm{Yb}$.

Figure 5: Various trace element ratios and other quantities associated with alteration in Jack Hills zircons versus the LREE-I parameter. Breaks in slope are common between LREE-I values of 10-30. A) apparent $\mathrm{T}^{\mathrm{xlln}}$; B) P; C) $\mathrm{Fe}^{*}$; D) time-corrected $\mathrm{U}$. Subscript ' $t$ ' indicates decay-corrected value for crystallization age. Asterisk on $\mathrm{Fe}^{*}$ indicates this is an estimated concentration because the NIST 610 standard glass 
576

577

578

579

580

581

582

583

584

585

586

587

588

589

590

591

592

593

594

595

596

597

598

599

600

601

602

603

604

605

606

607

may have an unresolved interference on mass ${ }^{57} \mathrm{Fe}$ lending uncertainty to the absolute concentration calculations.

Figure 6: Various quantities that may differ with either magmatic processes or alteration versus the LREE-I parameter. Breaks in slope or reversals in trends at high LREE-I are common at values of 30-10 (noted by dashed lines). A) time-corrected $\mathrm{Th} / \mathrm{U} ; \mathrm{B}$ ) $\mathrm{Yb} / \mathrm{Gd}$; C) $\mathrm{Ce} / \mathrm{Ce}^{*}$; D) apparent $\triangle \mathrm{FMQ}$.

Figure 7: Sm/La, a proposed criterion for recognizing hydrothermal alteration (Hoskin, 2005), versus A) La concentration and B) the LREE-I, along with approximate fields for magmatic and hydrothermal zircons from Hoskin (2005). For the most part, low-Sm/La zircons (i.e., likely to be hydrothermal) also display low LREE-I (i.e., altered), although a small group of high-LREE-I (i.e., apparently unaltered) zircons display low Sm/La. LREE-I values of 10 and 30 are noted by dashed lines.

Figure 8: Probability density functions for A) apparent $\mathrm{T}^{\mathrm{xlln}}$ and B) $\log _{10}(\mathrm{Sm} / \mathrm{La})$ for both all Jack Hills zircons data and those data with LREE-I $>30$ (primary).

Figure 9: The LREE-altered and ambiguous cases classified by age of the host zircon and showing Feand P-related alteration. A) Apparent $\mathrm{T}^{\mathrm{xlln}}$ versus Fe; B) time-corrected $\mathrm{U}$ versus $\mathrm{Fe}$; C) time-corrected Th/U versus P; D) Y versus P. Contamination with REE-Y-bearing phosphates (likely xenotime) and Tibearing Fe oxides is likely to account for most of the altered (LREE-I $<10$ ) samples. Some variation in age of the host zircon is seen, with most Hadean cases having lower Fe*, P, Y, and Ti. Fe* is an estimated Fe concentration, as for Figure 5.

Figure 10: Various trace element quantities versus $\delta^{18} \mathrm{O}$, with groups classified in panels A-C by whether the $\delta^{18} \mathrm{O}$ analysis spot fell on a cracked or uncracked surface. A) LREE-I; B) $\triangle F M Q$; C) chondritenormalized $\mathrm{Sm} / \mathrm{La}$; D) chondrite-normalized $\mathrm{Sm} / \mathrm{La}$, grouped by zones and undifferentiated by $\delta^{18} \mathrm{O}$ spot placement. Panel A shows trace element analyses regardless of LREE-I category. Panels B-D show trace element analyses falling into the "primary" category (LREE-I $>30$ ) but undifferentiated by relationship to cracks.Zoning styles in panel D: "mag" = magmatic; "hom" = homogeneous; "b.r." = bright replacement.

Figure 11: Trace element variations among the primary dataset, grouped by age category. A) Y vs. $(\mathrm{Th} / \mathrm{U})_{t}$; B) $\mathrm{Yb} / \mathrm{Hf}$ vs. $(\mathrm{Th} / \mathrm{U})_{t}$; C) $\mathrm{Yb} / \mathrm{Gd}$ vs. $(\mathrm{Th} / \mathrm{U})_{t}$; D) $\mathrm{Yb} / \mathrm{Gd}$ vs. $\left.(\mathrm{Sm} / \mathrm{La})_{\mathrm{N}} ; \mathrm{E}\right) \mathrm{Gd}$ vs. $\left.(\mathrm{Sm} / \mathrm{La})_{\mathrm{N}} ; \mathrm{F}\right)$ $\mathrm{Ce} / \mathrm{Ce}^{*}$ vs. $(\mathrm{Sm} / \mathrm{La})_{\mathrm{N}}$. 


\section{References}

621

622

623
Barth, A.P., Wooden, J.L., Jacobson, C.E., Economos, R.C., 2013. Detrital zircon as a proxy for tracking the magmatic arc system: The California arc example. Geology 41, 223-226.

Bell, E.A., Boehnke, P., Harrison, T.M., Mao, W.L., 2015a. Potentially biogenic carbon preserved in a 4.1 Ga zircon. Proc. Nat. Acad. Sci. 112, 14518-14521.

Bell, E.A., Boehnke, P., Hopkins-Wielicki, M.D., Harrison, T.M., 2015b. Distinguishing primary and secondary inclusion assemblages in Jack Hills zircons. Lithos 234-235, 15-26.

Bell, E.A., Harrison, T.M., 2013. Post-Hadean transitions in Jack Hills zircon provenance: a signal of the Late Heavy Bombardment? Earth and Planetary Science Letters 364, 1-11.

Bell, E.A., Harrison, T.M., Kohl, I.E., Young, E.D., 2014. Eoarchean crustal evolution of the Jack Hills zircon source and loss of Hadean crust. Geochimica et Cosmochimica Acta 146, 27-42.

Bell, E.A., Harrison, T.M., McCulloch, M.T., Young, E.D., 2011. Early Archean crustal 
641

642

643

644

645

646

647

648

649

650

651

652

653

654

655

656

657

658

659

660

661

662

663

664

665

666

evolution of the Jack Hills Zircon source terrane inferred from Lu-Hf, ${ }^{207} \mathrm{~Pb} /{ }^{206} \mathrm{~Pb}$, and $\delta^{18} \mathrm{O}$ systematics of Jack Hills zircons. Geochimica et Cosmochimica Acta75, 48164829.

Belousova, E.A., Griffin, W.L., O’Reilly, S.Y., Fisher, N.I., 2002. Igneous zircon: trace element composition as an indicator of source rock type. Contributions to Mineralogy and Petrology143, 602-622.

Blichert-Toft, J., Albarède, F., 2008. Hafnium in Jack Hills zircons and the formation of the Hadean crust. Earth and Planetary Science Letters 265, 686-702.

Caro, G., Bennett, V.C., Bourdon, B., Harrison, T.M., von Quadt, A., Mojzsis, S.J., Harris, J.W., 2008. Application of precise ${ }^{142} \mathrm{Nd} /{ }^{144} \mathrm{Nd}$ of small samples to inclusions in diamonds (Finch, South Africa) and Hadean zircons (Jack Hills, Western Australia). Chemical Geology247, 253-265.

Cavosie, A.J., Quintero, R.R., Radovan, H.A., Moser, D.E., 2010. A record of ancient cataclysm in modern sand: Shock microstructures in detrital minerals from the Vaal River, Vredefort Dome, South Africa. GSA Bulletin122, 1968-1980.

Cavosie, A.J., Valley, J.W., Wilde, S.A., E.I.M.F., 2005. Magmatic $\delta^{18} \mathrm{O}$ in 4400-3900 Ma detrital zircons: A record of the alteration and recycling of crust in the Early Archean. Earth and Planetary Science Letters 235, 663-681.

Cavosie, A.J., Valley, J.W., Wilde, S.A., E.I.M.F., 2006. Correlated microanalysis of zircon: Trace element, $\mathrm{d} 18 \mathrm{O}$, and $\mathrm{U}-\mathrm{Th}-\mathrm{Pb}$ isotopic constraints on the igneous origin of complex >3900 Ma detrital grains. Geochimica et Cosmochimica Acta70, 5601-5616.

Cavosie, A.J., Wilde, S.A., Liu, D., Weiblen, P.W., Valley, J.W., 2004. Internal zoning and UTh- $\mathrm{Pb}$ chemistry of Jack Hills detrital zircons: a mineral record of early Archean to Mesoproterozoic (4348-1576 Ma) magmatism. Precambrian Research135, 251-279.

Claiborne, L.L., Miller, C.F., Wooden, J.L., 2010. Trace element composition of igneous zircon: a thermal and compositional record of the accumulation and evolution of a large silicic batholith, Spirit Mountain, Nevada. Contributions to Mineralogy andPetrology160, 511-531.

Compston, W., Pidgeon, R.T., 1986. Jack Hills, evidence of more very old detrital zircons in Western Australia. Nature321, 766-769.

Coogan, L.A., Hinton, R.W., 2006. Do the trace elements compositions of detrital zircons require Hadean continental crust? Geology34, 633-636.

Corfu, F., Hanchar, J.M., Hoskin, P.W.O., Kinny, P., 2003. Atlas of zircon textures. In Hanchar, J.M., Hoskin, P.W.O, eds., Zircon. Reviews in Mineralogy53, 469-500. 
Crowley J.L., Myers J.S., Sylvester P.J., Cox R.A., 2005. Detrital zircon from the Jack Hills and Mount Narryer, Western Australia: Evidence for diverse $>4.0$ Ga source rocks. Journal of Geology113, 239-63.

De Hoog, J.C.M., Lissenberg, C.J., Brooker, R.A., Hinton, R., Trail, D., Hellebrand, E., 2014. Hydrogen incorporation and charge balance in natural zircon. Geochimica et Cosmochimica Acta141, 472-486.

Ferry, J.M., Watson, E.B., 2007.New thermodynamic models and revised calibrations for the Tiin-zircon and Zr-in-rutile thermometers. Contributions to Mineralogy and Petrology154, 429437.

Finch, R.J., Hanchar, J.M., 2003.Structure and chemistry of zircon and zircon-group minerals. In Hanchar, J.M., Hoskin, P.W.O, eds., Zircon.Reviews in Mineralogy and Geochemistry53, 125.

Fletcher, I.R., Rosman, K.J.R., Libby, W.G., 1988. Sm-Nd, Pb-Pb and Rb-Sr geochronology of the Manred Complex, Mount Narryer, Western Australia. Precambrian Research 38, 343354.

Fu, B., Page, F.Z., Cavosie, A.J., Fournelle, J., Kita, N.T., Lackey, J.S., Wilde, S.A., Valley, J.W., 2008. Ti-in-zircon thermometry: applications and limitations. Contributions to Mineralogy and Petrology156, 197-215.

Geisler, T., Pidgeon, R.T., Kurtz, R., Bronswijk, W.V., Schleicher, H., 2003a. Experimental hydrothermal alteration of partially metamict zircon. American Mineralogist88, 1496-1513.

Geisler, T., Rashwan, A.A., Rahn, M.K.W., Poller, U., Zwingmann, H., Pidgeon, R.T., Schleicher, H., Tomaschek, F., 2003b. Low-temperature hydrothermal alteration of natural metamict zircons from the Eastern Desert, Egypt. Mineralogical Magazine67, 485-508.

Gieré, R., 1996. Formation of rare earth minerals in hydrothermal systems. In Jones, A.P., Wall, F., Williams, C.T., eds. Rare Earth Minerals: Chemistry, origin and ore deposits, 105-150. Chapman and Hall, London, UK.

Grimes, C.B., John, B.E., Kelemen, P.B., Mazdab, F.K., Wooden, J.L., Cheadle, M.J., Hanghoj, K., Schwartz, J.J., 2007. Trace element chemistry of zircons from oceanic crust: a method for distinguishing detrital zircon provenance. Geology35, 643-646.

Hanchar, J.M., Miller, C.F., 1993. Zircon zonation patterns as revealed by cathodoluminescence and backscattered electron images: Implications for interpretation of complex crustal histories, Chemical Geology110, 1-13

Harrison, T.M., Watson, E.B., Aikman, A.B., 2007. Temperature spectra of zircon crystallization in plutonic rocks. Geology35, 635-638.

Harrison, T.M., Schmitt, A.K., 2007. High sensitivity mapping of Ti distributions in Hadean zircons. Earth and Planetary Science Letters 261, 9-19. 
Harrison, T. M., Trail, D., Schmitt, A.K., 2007 Rutile ${ }^{207} \mathrm{~Pb}{ }^{206} \mathrm{~Pb}$ ages in the Jack Hills quartzite, Western Australia. Geochimica et Cosmochimica Acta71, Supplement 1, A383.

Harrison T.M., Schmitt A.K., McCulloch M.T., Lovera O.M., 2008.Early ( $\geq 4.5 \mathrm{Ga}$ ) formation of terrestrial crust: Lu-Hf, $\delta 18 \mathrm{O}$, and Ti thermometry results for Hadean zircons. Earth and Planetary Science Letters 268, 476-86.

Harrison, T.M.,Blichert-Toft, J.,Müller,W.,Albarede, F.,Holden, P.,Mojzsis, S.J., 2005. Heterogeneous Hadean hafnium: evidence of continental crust by 4.4-4.5 Ga. Science 310, 1947-1950.

Holden, P., Lanc, P., Ireland, T.R., Harrison, T.M., Foster, J.J., Bruce, Z., 2009. Massspectrometric mining of Hadean zircons by automated SHRIMP multi-collector and singlecollector $\mathrm{U} / \mathrm{Pb}$ zircon age dating: The first 100,000 grains. International Journal of Mass Spectrometry 286, 53-63.

Hopkins, M., Harrison, T.M., Manning, C.E. 2008. Low heat flow inferred from >4 Gyr zircons suggests Hadean plate boundary interactions. Nature456, 493-496.

Hopkins, M., Harrison, T.M., Manning, C.E. 2010. Constraints on Hadean geodynamics from mineral inclusions in >4 Ga zircons. Earth and Planetary Science Letters 298, 367-376.

Hopkins, M.D., Mojzsis, S.J., 2015. A protracted timeline for lunar bombardment from mineral chemistry, Ti thermometry and $\mathrm{U}-\mathrm{Pb}$ geochronology of Apollo 14 melt breccia zircons. Contributions to Mineralogy and Petrology 169, 1-18.

Hoskin, P.W.O., 2005. Trace-element composition of hydrothermal zircon and the alteration of Hadean zircon from the Jack Hills, Australia. Geochimica et Cosmochimica Acta69, 637648.

Hoskin, P.W.O., Black, L.P., 2000. Metamorphic zircon formation by solid-state recrystallization of protolith igneous zircon. Journal of Metamorphic Geology18, 423-439.

Hoskin, P.W.O., Ireland, T.R., 2000. Rare earth element chemistry of zircon and its use as a provenance indicator. Geology28, 627-630.

Hoskin, P.W.O., Kinny, P.D., Wyborn, B., Chappell, B.W., 2000. Identifying accessory mineral saturation during differentiation of granitoid magmas: an integrated approach. Journal of Petrology41, 1365-1396.

Hoskin, P.W.O., Schaltegger, U., 2003. The composition of zircon and igneous and metamorphic petrogenesis. In Hanchar, J.M., Hoskin, P.W.O., eds., Zircon. Reviews in Mineralogy and Geochemistry 53, 343-385.

Hughes, J.M., Rakovan, J.F., 2015. Structurally robust, chemically diverse: apatite and apatite supergroup minerals. Elements 11, 165-170. 
Kemp, A.I.S., Wilde, S.A., Hawkesworth, C.J., Coath, C.D., Nemchin, A., Pidgeon, R.T., Vervoort, J.D., DuFrane, S.A., 2010. Hadean crustal evolution revisited: new constraints from $\mathrm{Pb}-\mathrm{Hf}$ isotope systematics of the Jack Hills zircons. Earth and Planetary Science Letters296, 45-56.

Kinny, P.D., Williams, I.S., Froude, D.O., Ireland, T.R., Compston, W., 1988. Early Archaean zircon ages from orthogneisses and anorthosites at Mount Narryer, Western Australia. Precambrian Research38, 325-341.

Maas, R., Kinny, P.D., Williams, I.S., Froude, D.O., Compston, W., 1992. The Earth's oldest known crust: A geochronological and geochemical study of 3900-4200 Ma old detrital zircons from Mt. Narryer and Jack Hills, Western Australia. Geochimica et Cosmochimica Acta56, 1281-1300.

Mezger, K., Krogstad, E.J., 1997. Interpretation of discordant U-Pb zircon ages: An evaluation. Journal of Metamorphic Geology 15, 127-140.

Mojzsis S.J., Devaraju T.C., Newton R.C., 2003. Ion microprobe U-Pb age determinations on zircon from the late Archean granulite facies transition zone of southern India. Journal of Geology111, 407-425.

Mojzsis, S.J., Harrison, T.M., Pidgeon, R.T., 2001. Oxygen-isotope evidence from ancient zircons for liquid water at the Earth's surface 4300 Myr ago. Nature 409, 178-181.

Moser, D.E., Cupelli, C.L., Barker, I.R., Flowers, R.M., Bowman, J.R., Wooden, J., Hart, J.R., 2011. New zircon shock phenomena and their use for dating and reconstruction of large impact structures revealed by electron nanobeam (EBSD, CL, EDS) and isotopic U-Pb and (U-Th)/He analysis of the Vredefort dome. Canadian Journal of Earth Sciences48, 117-139.

Myers, J.S., 1988a. Early Archaean Narryer Gneiss Complex, Yilgarn Craton, Western Australia. Precambrian Research38, 297-307.

Myers, J.S., 1988b. Oldest known terrestrial anorthosite at Mount Narryer, Western Australia. Precambrian Research38, 309-323.

Nutman, A.P., Kinny, P.D., Compston, W., Williams, I.S., 1991. SHRIMP U-Pb zircon geochronology of the Narryer Gneiss Complex, Western Australia. Precambrian Research52, 275-300.

Paces, J.B., Miller, J.D., 1993. Precise U-Pb ages of Duluth Complex and related mafic intrusions, northeastern Minnesota: Geochronological insights into physical, petrogenetic, and paleomagnetic and tectonomagnetic processes associated with the $1.1 \mathrm{Ga}$ mid-continent rift system. Journal of Geophysical Research98, 13,997-14,013.

Pearce, J.A., Harris, N.B., Tindle, A.G., 1984. Trace element discrimination diagrams for the tectonic interpretation of granitic rocks. Journal of Petrology25, 956-983. 
Peck, W.H., Valley, J.W., Wilde, S.A., Graham, C.M., 2001. Oxygen isotope ratios and rare earth elements in 3.3-4.4 Ga zircons: Ion microprobe evidence for high $\delta^{18} \mathrm{O}$ continental crust and oceans in the Early Archean. Geochimica et Cosmochimica Acta65, 42154299.

Pidgeon, R.T., 2014. Zircon radiation damage ages. Chemical Geology367, 13-22.

Pidgeon, R.T., Nemchin, A.A., Hitchen, G.J., 1998. Internal structures of zircons from Archaean granites from the Darling Range batholith: implications for zircon stability and the interpretation of zircon U-Pb ages. Contributions to Mineralogy and Petrology32, 288-299.

Rasmussen, B., Fletcher, I.R., Muhling, J.R., Gregory, C.J., Wilde, S.A., 2011. Metamorphic replacement of mineral inclusions in detrital zircon from Jack Hills, Australia: Implications for the Hadean Earth. Geology 39, 1143-1146.

Rasmussen, B., Fletcher, I.R., Muhling, J.R., Wilde, S.A., 2010. In situ U-Th-Pb geochronology of monazite and xenotime from the Jack Hills belt: Implications for the age of deposition and metamorphism of Hadean zircons. Precambrian Research 180, 2646.

Schoene, B., Latkoczy, C., Schaltegger, U., Günther, D., 2010. A new method integrating high-precision $\mathrm{U}-\mathrm{Pb}$ geochronology with zircon trace element analysis (U-Pb TIMSTEA). Geochimica et Cosmochimica Acta 74, 7144-7159.

Spaggiari, C.V., Pidgeon, R.T., Wilde, S.A., 2007. The Jack Hills greenstone belt, Western Australia Part 2: Lithological relationships and implications for the deposition of $\geq 4.0 \mathrm{Ga}$ detrital zircons. Precambrian Research 155, 261-286.

Tarduno, J.A., Cottrell, R.D., Davis, W.J., Nimmo, F., Bono, R.K., 2015. A Hadean to Paleoarchean geodynamo recorded by single zircon crystals. Science 349, 521-524.

Trail, D., Mojzsis, S.J., Harrison, T.M., Schmitt, A.K., Watson, E.B., Young E.D., 2007. Constraints on Hadean zircon protoliths from oxygen isotopes, REEs and Tithermometry. Geochemistry Geophysics Geosystems8, Q06014.

Trail, D., Watson, E.B., Tailby, N.D., 2011. The oxidation state of Hadean magmas and implications for early Earth/'s atmosphere. Nature 480, 79-82.

Valley, J.W., 2003. Oxygen isotopes in zircon. Reviews in mineralogy and geochemistry53, 343385.

Vavra, G., Schmid, R., Gebauer, D., 1999. Internal morphology, habit and U-Th-Pb microanalysis of amphibolite-to-granulite facies zircons: geochronology of the Ivrea Zone (Southern Alps). Contributions to Mineralogy and Petrology34, 380-404.

Wall, F., Mariano, A.N., 1996. Rare earth minerals in carbonatites: a discussion centred on the Kangankunde Carbonatite, Malawi. In Jones, A.P., Wall, F., Williams, C.T., eds. 
Rare earth minerals: Chemistry, origin and ore deposit. Chapman \& Hall, London, 193225.

Watson, E.B., Cherniak, D.J., 1997. Oxygen diffusion in zircon. Earth and Planetary Science Letters 148, 527-544.

Watson, E.B., Harrison, T.M., 2005. Zircon thermometer reveals minimum melting conditions on earliest Earth. Science 308, 841-844.

Weiss, B.P., Maloof, A.C., Tailby, N., Ramezani, J., Fu, R.R., Hanus, V., Trail, D., Watson, E.B., Harrison, T.M., Bowring, S.A., Kirschvink, J.L., Swanson-Hysell, N.L., Coe, R.S., 2015. Pervasive remagnetization of detrital zircon host rocks in the Jack Hills, Western Australia and implications for records of the early geodynamo. Earth and Planetary Science Letters430, 115-128.

Wiedenbeck, M., Hanchar, J.M., Peck, W.H., Sylvester, P., Valley, J., Whitehouse, M., Kronz, A., Morishita, Y., Nasdala, L., Fiebig, J., Franchi, I., Girard, J.-P., Greenwood, R.C., Hinton, R., Kita, N., Mason, P.R.D., Norman, M., Ogasawara, M., Piccoli, P.M., Rhede, D., Satoh, H., Schulz-Dobrick, B., Skår, O., Spicuzza, M.J., Terada, K., Tindle, A., Togashi, S., Vennemann, T., Xie, Q., Zheng, Y.F., 2004. Further characterisation of the 91500 zircon crystal. Geostandards and Geoanalytical Research 28, 9-39.

Wielicki, M.T., Harrison, T.M., and Schmitt, A.K. 2012. Geochemical signatures and magmatic stability of impact produced zircons. Earth and Planetary Science Letters321-322, 20-31.

Wilde, S.A., 2010. Proterozoic volcanism in the Jack Hills Belt, Western Australia: Some implications and consequences for the World's oldest zircon population. Precambrian Research 183, 9-24.

Williams, I.R., Myers, J.S., 1987. Archean geology of the Mount Narryer region, Western Australia. Western Australian Geological Survey Report22: 32 pp.

Winter, J.D., 2001. An introduction to igneous and metamorphic petrology. Prentice Hall, NJ, USA.

Yang, W.B., Niu, H.C., Shan, Q., Sun, W.D., Zhang, H., Li, N.B., Jiang, Y.H., Yu, X.Y., 2014. Geochemistry of magmatic and hydrothermal zircon from the highly evolved Baerzhe alkaline granite: implications for $\mathrm{Zr}-\mathrm{REE}-\mathrm{Nb}$ mineralization. Mineralium Deposita49, 451-470. 
bright;

replacement?
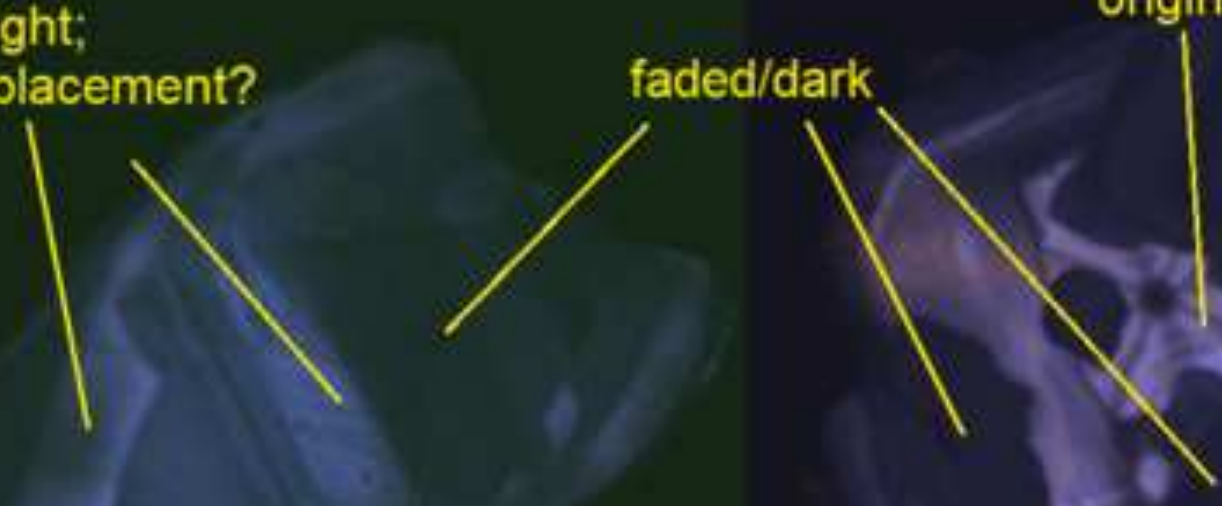

originally magmatic

Linimin

प्राm

A

B

Linininime

faded magmatic

bright; replacement?
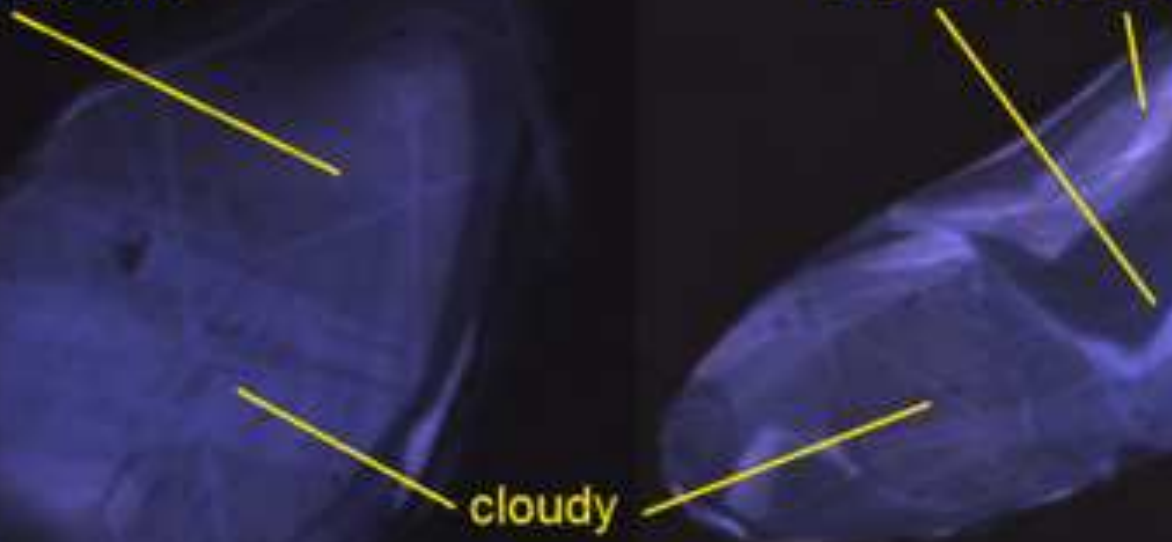

C

Hining

D

overall: patchy

Linimu

$100=$

remnant magmatic zoning

xenotime
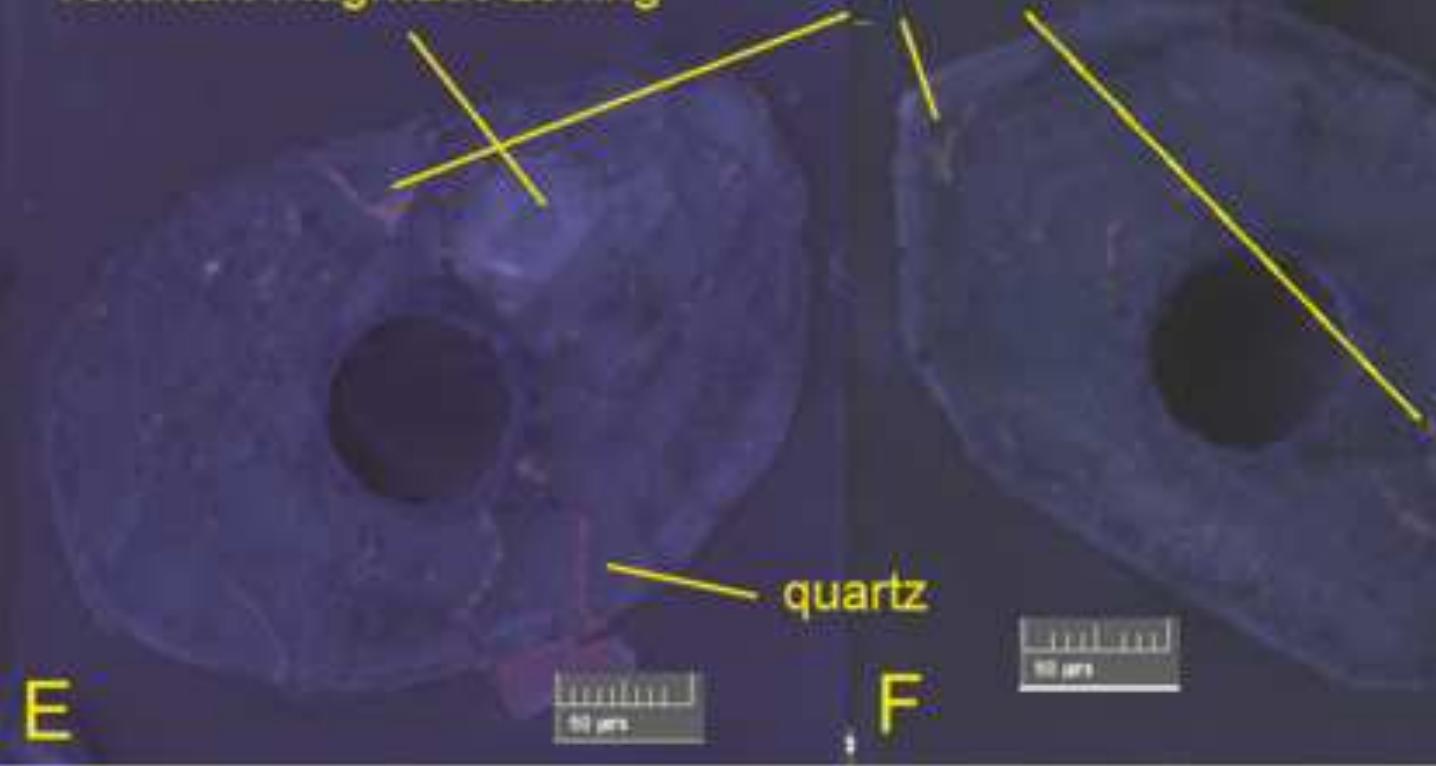

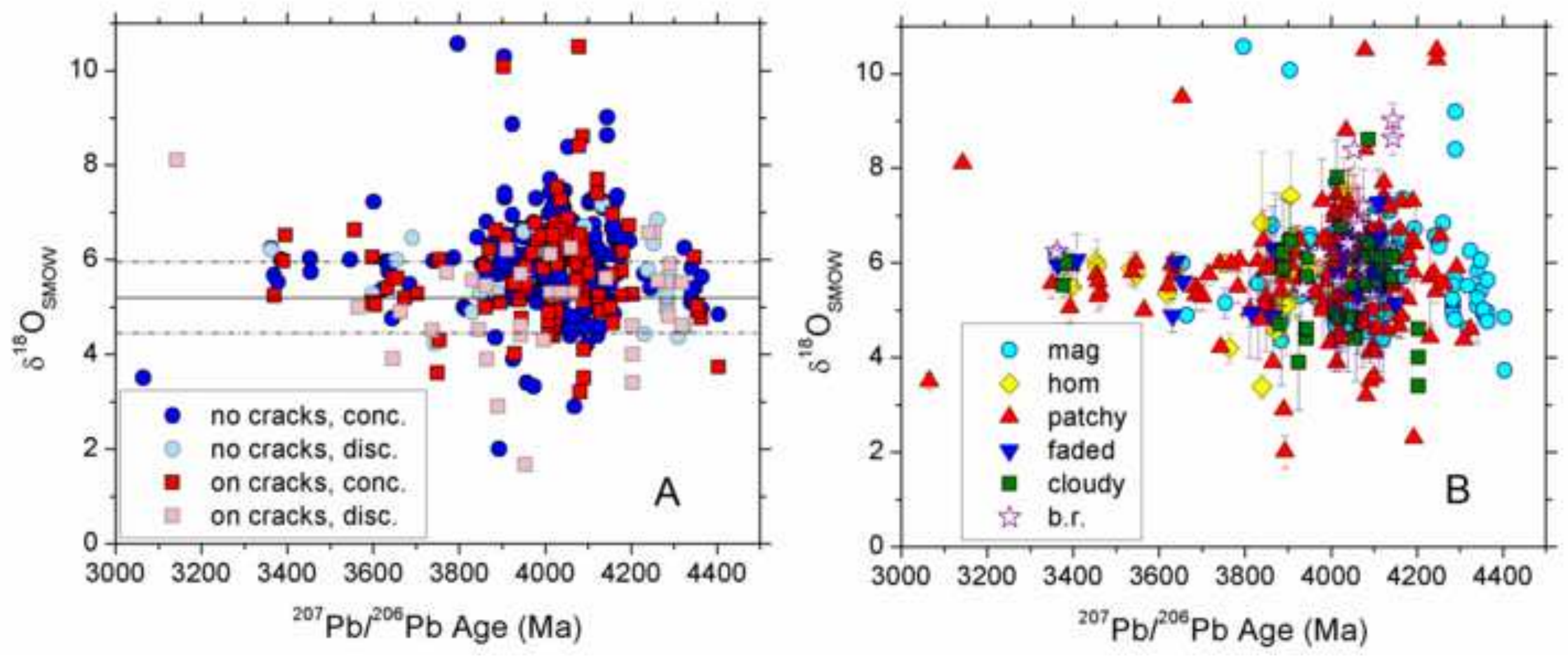


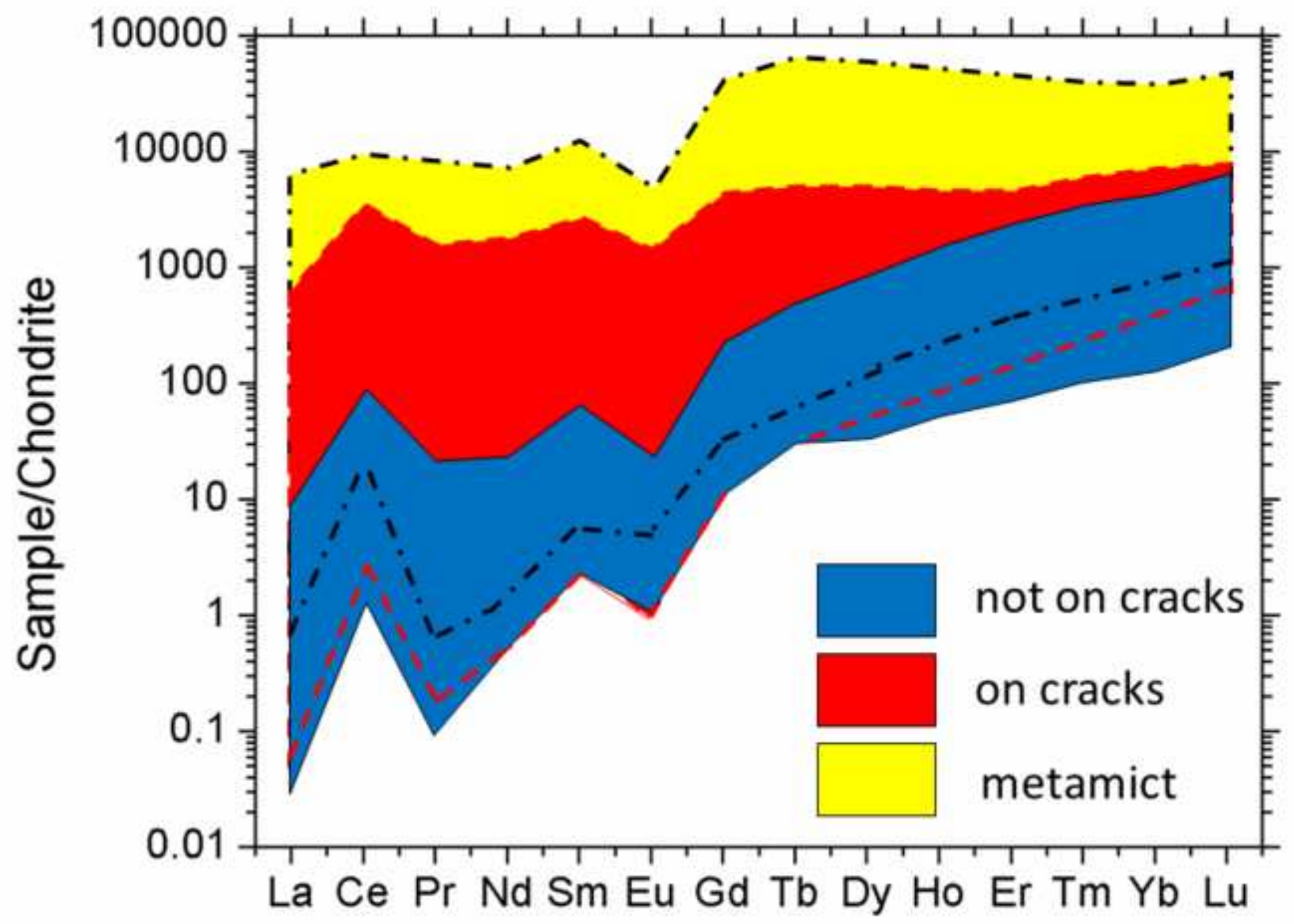


Figure 4
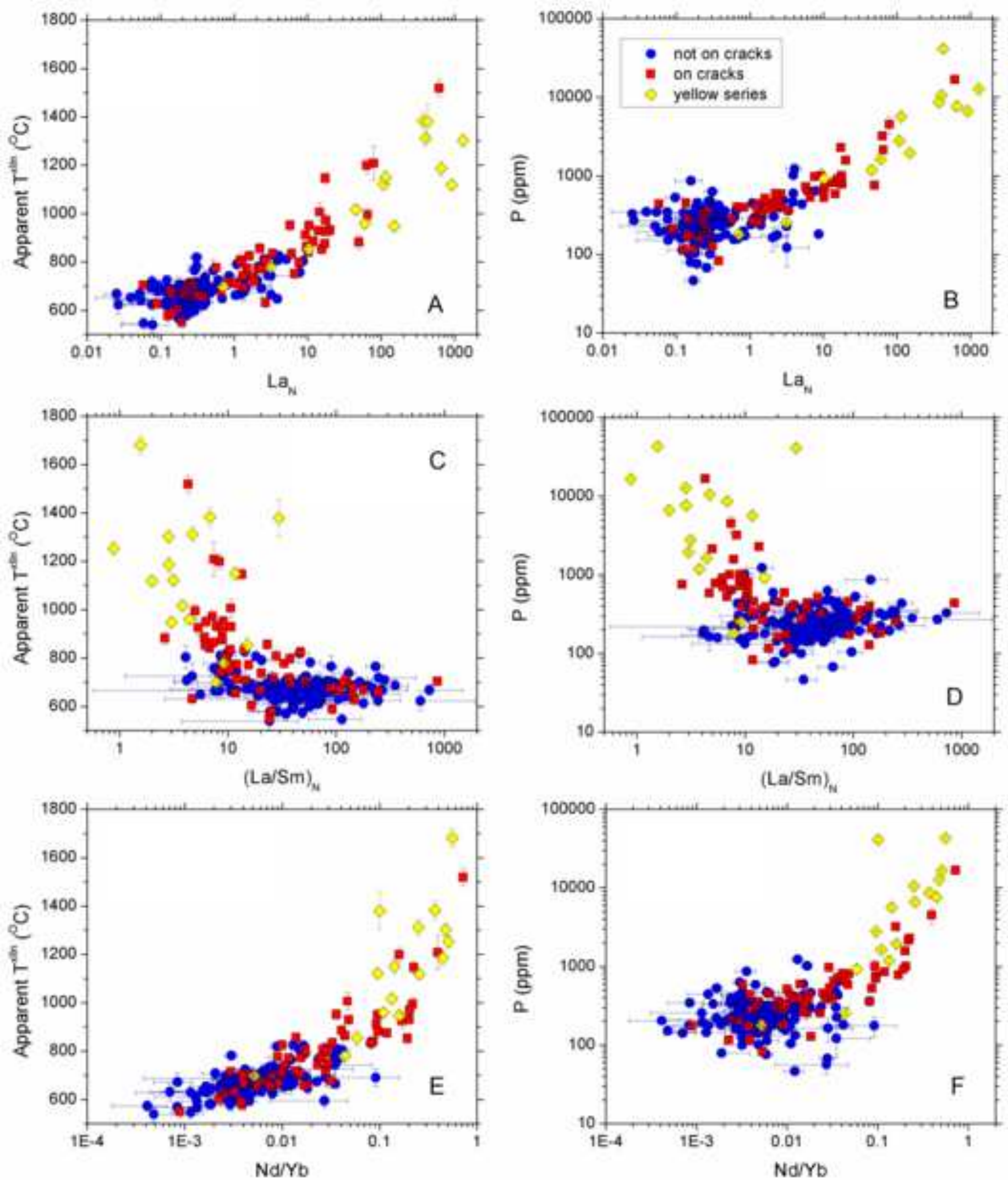

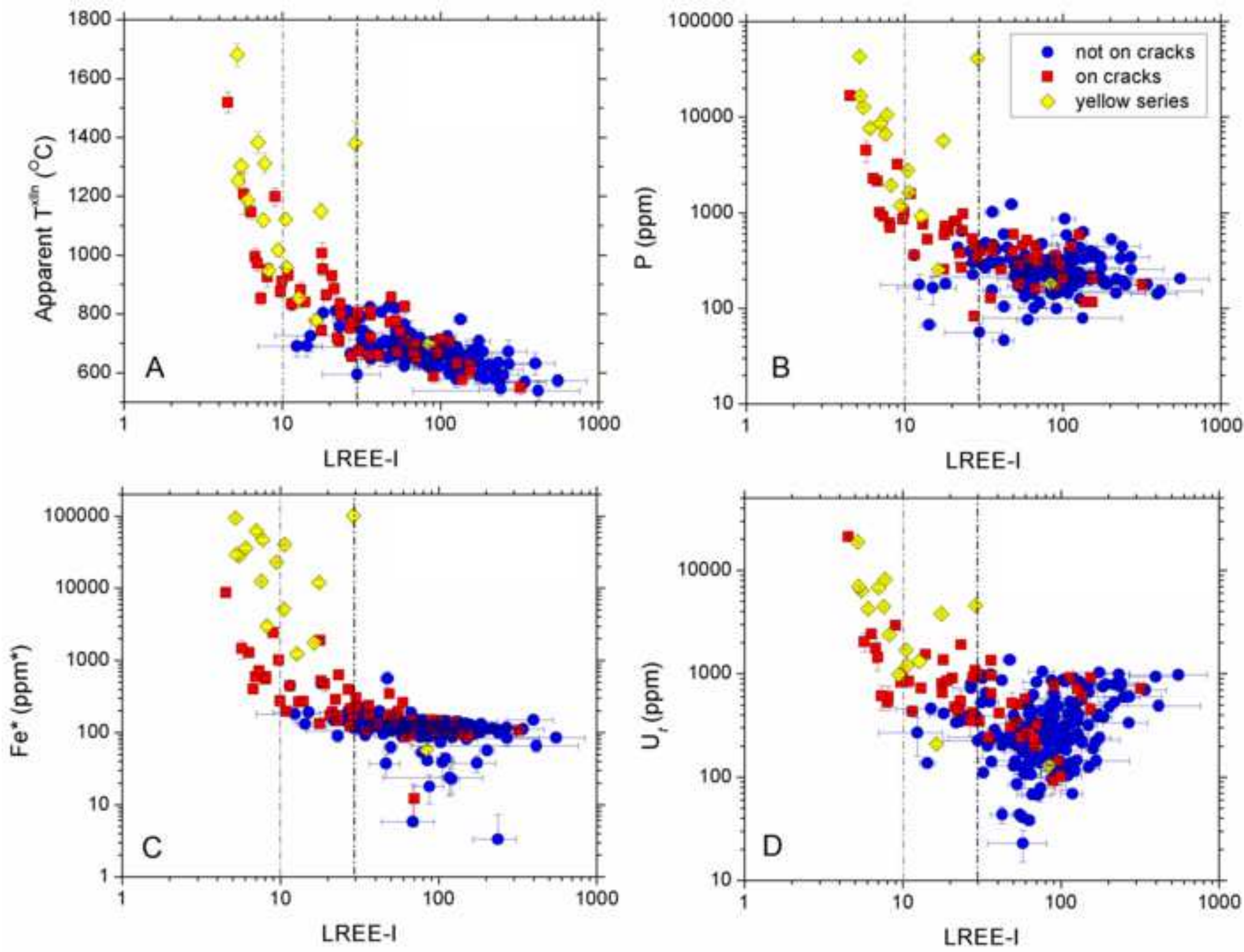

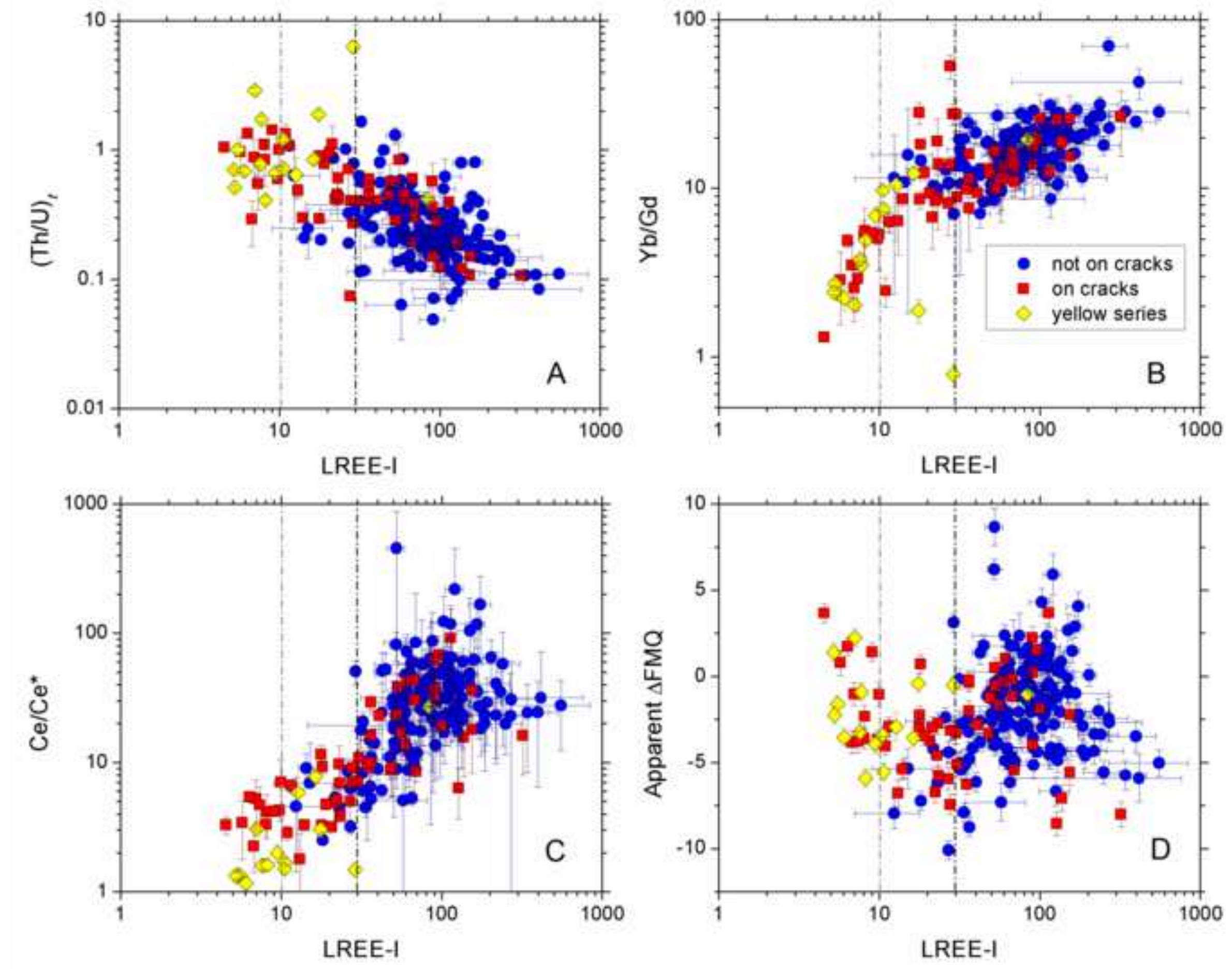

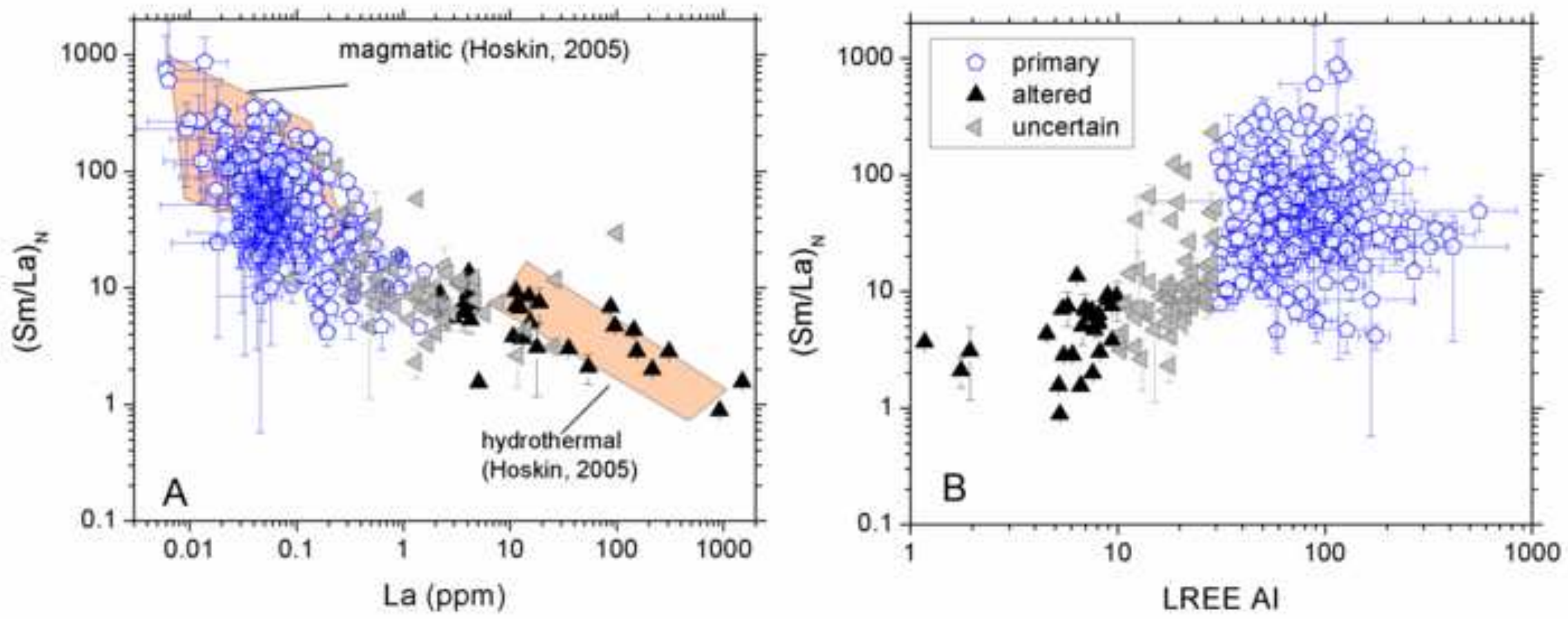

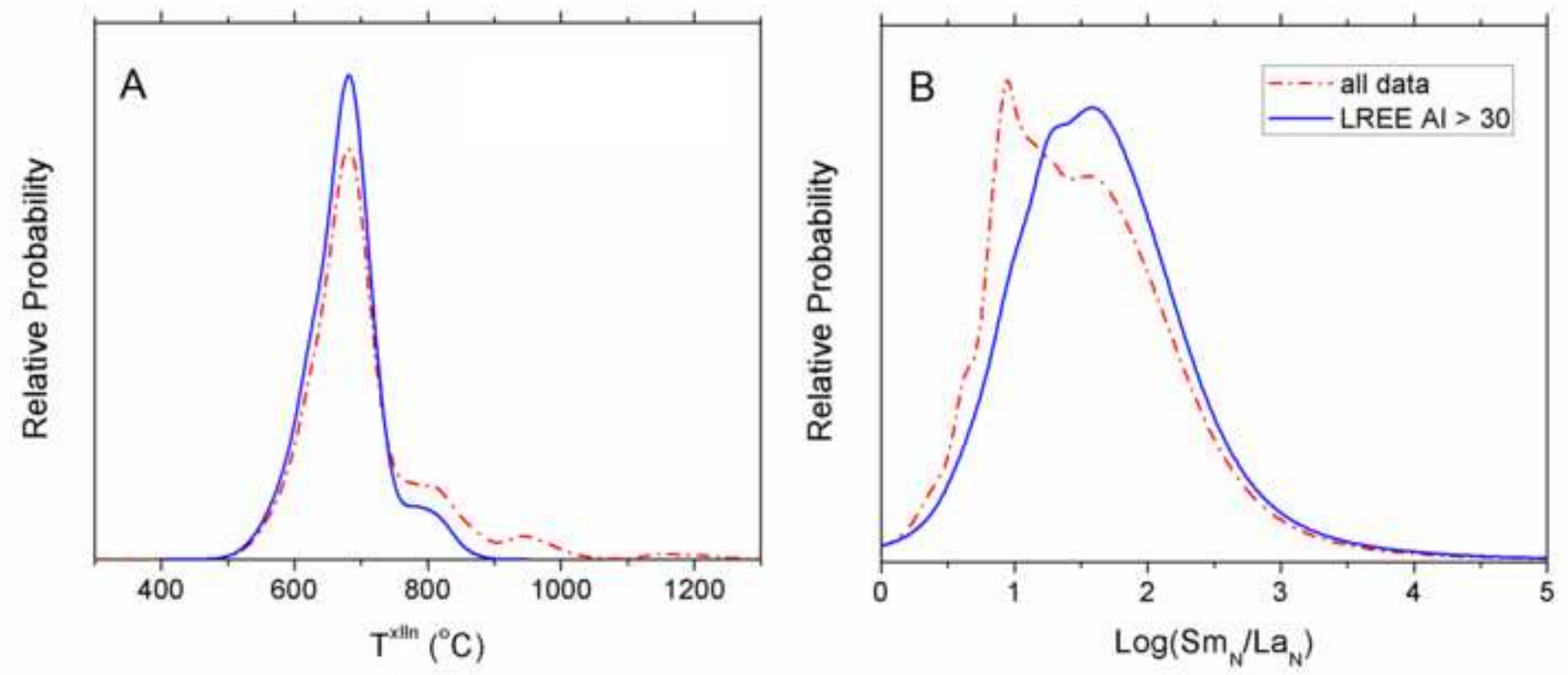

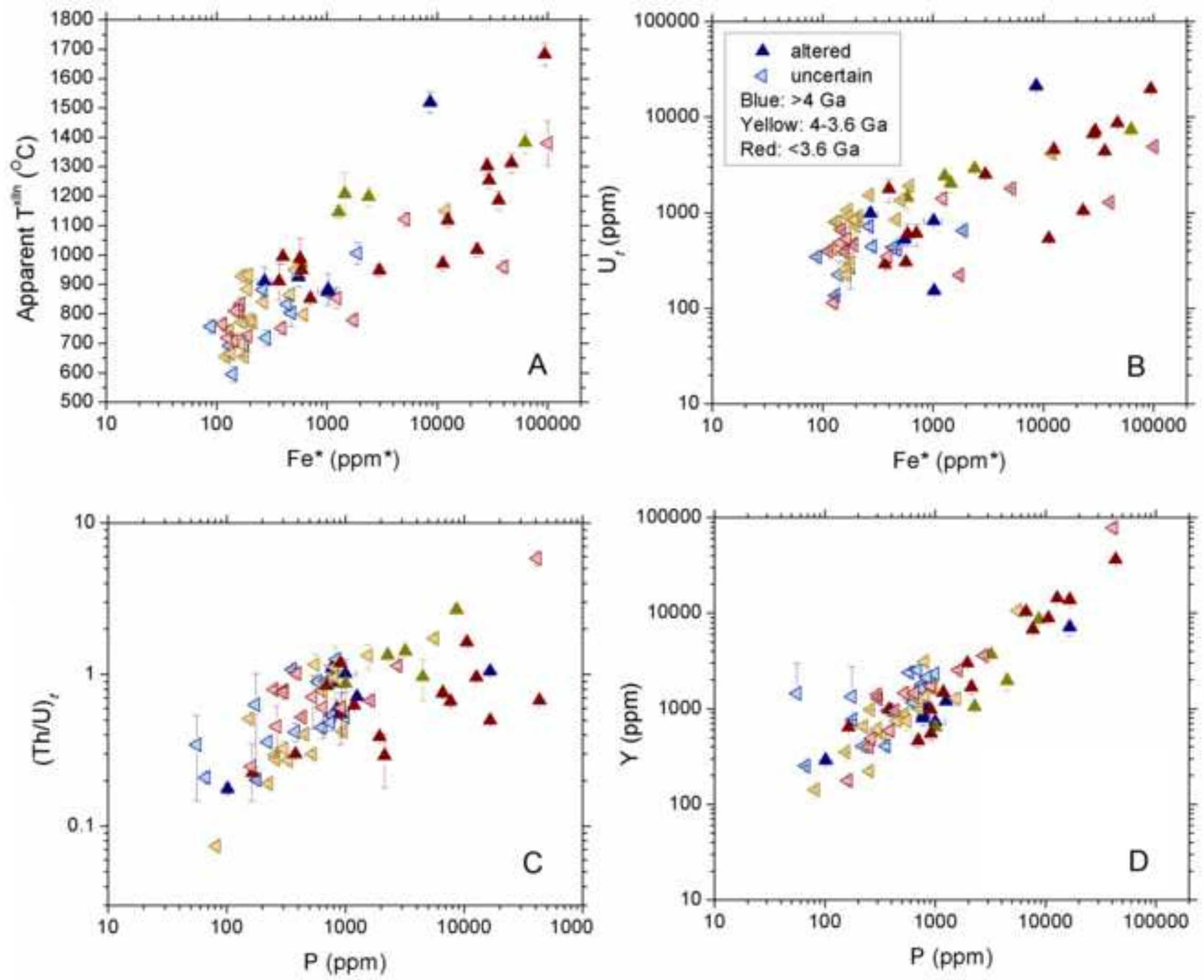

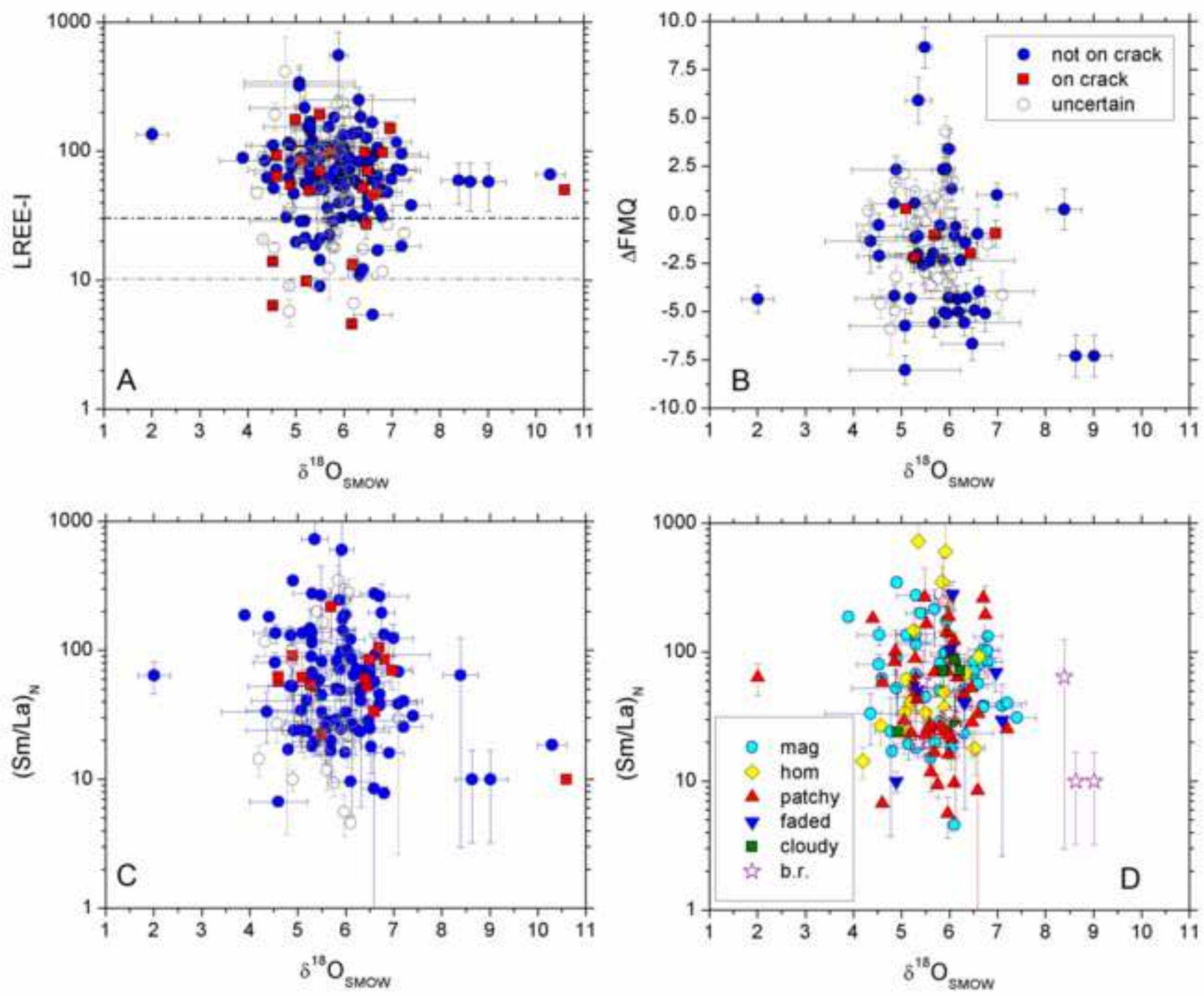

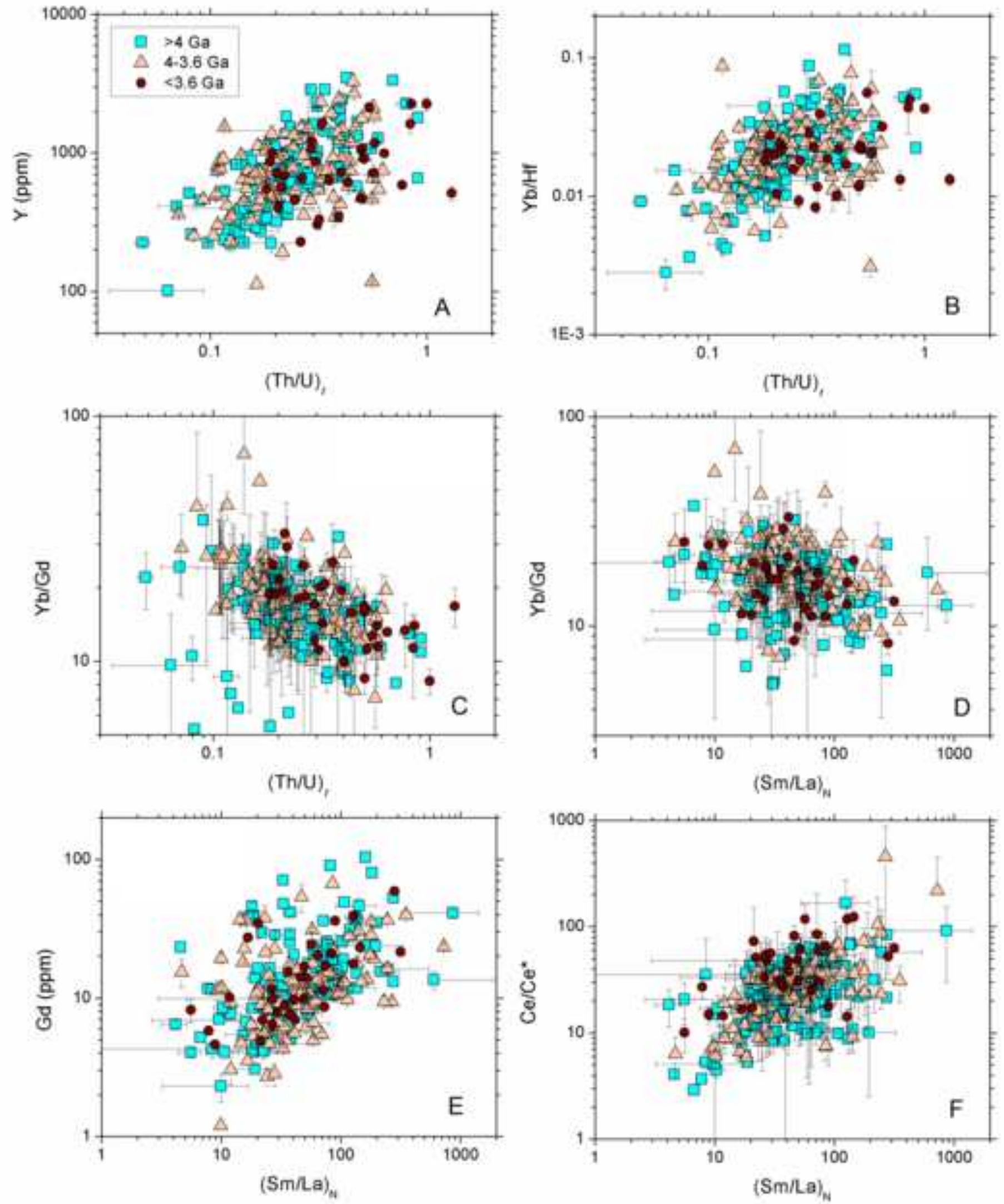